\title{
FINAL DRAFT Innovations in framework synthesis as a systematic review method
}

Last updated: 11 January 2019

Journal: Research Synthesis Methods

Authors: Ginny Brunton, James Thomas, Sandy Oliver

Submission guidance:

http://onlinelibrary.wiley.com/journal/10.1002/(ISSN)1759-

2887/homepage/ForAuthors.html

12-point type: Times, Helvetica, or Courier

Double-spacing not needed

AMA Referencing

Reviews offer a general overview of a particular field or topic, providing the reader with an appreciation of the importance of the work, a summary of recent developments, and a starting point in the specialist literature. Reviews are not limited as to the number of pages, tables, figures and references that may be included.

Abstract not more than 250 words

Keywords. Authors should prepare no more than 5 keywords for their Manuscript to help describe their paper for indexing purposes. 


\section{Abstract}

\section{Background}

Framework synthesis is increasingly used in systematic reviews of health care practice and policy. Adapted from framework analysis methods, it has been used in qualitative and mixed-method systematic reviews. This paper demonstrates how framework synthesis methods are situated within, and contribute to, wider debates about research synthesis methods.

\section{Methods}

An overview was conducted of systematic reviews which employed or discussed framework synthesis. Included reviews were ordered and synthesised using framework synthesis methods. Findings were subsequently incorporated into the conceptual framework and higher order themes derived using constant comparative analysis.

\section{Results}

We identified 43 publications describing 37 unique papers. These papers either applied framework synthesis in a systematic review, illustrated its use with examples, or situated framework synthesis within a range of systematic review methods.

\section{Discussion}

Two key approaches to framework synthesis emerged. One used mixed methods to accommodate research from across academic disciplines and policy sectors in order to construct, explore and/or test a conceptual framework (often in discussion with public stakeholders). Another employed a 'best-fit' approach that borrows a framework from a related area to initiate qualitative evidence synthesis within a narrower disciplinary or policy scope. Both approaches demonstrate the utility of framework synthesis in handling mixed methods and mixed sources reviews, using diverse data types and synthesis methods in order to generate, explore and test theory in collaboration with public and other stakeholders.

\section{Conclusions}

Framework synthesis provides a flexible research synthesis approach to meet the varied conditions and epistemology arising from health policy and practice issues. [249 words]

Keywords

Qualitative evidence synthesis, mixed methods reviews, systematic reviews, research methods, public health 


\section{INTRODUCTION}

Systematic reviews are widely used to synthesise research in order to inform policy and practice decisions ${ }^{1,2}$. Systematic reviews enable us to 'take stock' of the research in a field of inquiry by seeking out, selecting, critically assessing and synthesising the available research, using transparent, rigorous and replicable methods ${ }^{2-4}$. By identifying the most relevant research, it becomes possible to generalise research results to a wider population by looking for knowledge and findings across individual primary studies ${ }^{4}$. Systematic reviews can 'recast our view of research by challenging existing assumptions and suggesting new areas for investigation'(p.4) ${ }^{5}$ because they build on 'previous investments in research'(p.8) ${ }^{6}$. Typically intended to help decision-makers select an intervention from a range of options, systematic reviews seek to address not only whether an intervention works or not, but for which groups of people, and under what circumstances ${ }^{7}$. Efforts to understand these factors have led to an evolution of research synthesis methods. These have been designed to address research questions that examine issues which could precede, include and go beyond effectiveness ${ }^{8}$, incorporating mixed methods reviews and evidence syntheses of stakeholders' experiences ${ }^{5,9}$. Such questions require different approaches to synthesise review findings appropriately $y^{5,9}$.

Framework synthesis is one method employed within systematic reviews to examine this complexity ${ }^{10}$. It originates from framework analysis, a method of analysing primary research data to address policy concerns ${ }^{11}$. The research question and the background theoretical and empirical literature shape an understanding of the issue under study into an a priori conceptual framework, which develops iteratively as new data are incorporated and themes are derived from the data. Framework analysis presents an opportunity to use a 'scaffold against which findings from the different components of an assessment may be brought together and organised'(p.29) ${ }^{12}$. Its flexibility captures new understanding as data is incorporated into the framework. Used in the context of synthesizing the findings of prior research within a systematic review, it is described as 'framework synthesis' ${ }^{\text {10,12. }}$

Framework synthesis consists of five stages. In the familiarisation stage of framework synthesis, a reviewer becomes familiar with current issues and ideas about the topic under study, by drawing on a variety of sources ${ }^{11,13}$. This leads to framework selection: the choice of an initial conceptual framework or theory that might explain the issue. At the indexing stage, studies are sought, screened and data extracted using the initial conceptual framework. Here, studies are sorted to determine their relevance to the review questions and to identify their main characteristics. During the charting stage, the main characteristics of each study are analysed by grouping characteristics into categories and deriving themes 
directly from those data. Finally, at the mapping and interpretation stage, derived themes are considered in light of the original research questions. Findings from the review are presented in various formats (e.g. forest plots, tables, figures, or narratives) for ease of reader interpretation.

As shown in Figure 1, the stages of framework synthesis correspond to the systematic review process, but there is some overlap between stages and processes. For example, the familiarisation stage of framework synthesis occurs from a systematic review's initiation until well into searching for potentially relevant research.

Figure 1. Framework synthesis stages corresponding to the systematic review process

Systematic review processes (Gough et al. 2012)

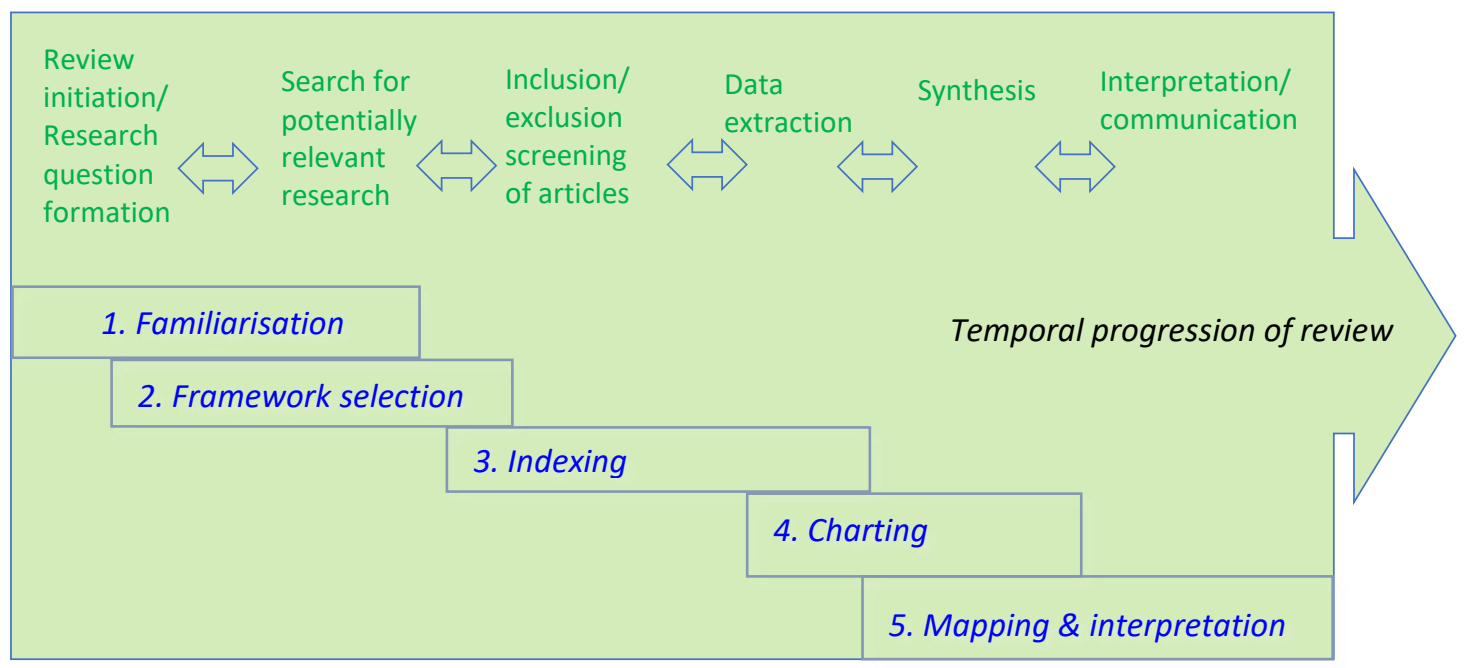

Stages of Framework synthesis method (Ritchie et al. 2014)

Systematic reviews currently describe varying methodologies for framework synthesis. For example, some reviews describe or suggest deductive approaches ${ }^{12}$, whilst others describe methods indicative of more inductive (or emergent) approaches ${ }^{14}$. Until recently, no in-depth consideration had been undertaken of the foundations of framework synthesis, when to use the method, the different ways it can be used, and what it can provide.

The systematic review described in this paper aims to examine what is known about framework analysis methods in health research synthesis by addressing three specific sub-questions:

1. How do methods of framework synthesis compare with other research synthesis methods? 
2. Where is framework synthesis located within the context of a range of research synthesis methods?

3. What problems are addressed by framework synthesis and not by other methods?

To address these questions, a systematic review was conducted of academic papers using or critically discussing framework synthesis methods. Each step of the review process that follows will be reported in relation to the stages of framework synthesis.

\section{METHODS}

\subsection{Familiarisation}

Background scoping of literature was undertaken in order to identify a relevant conceptual framework to which included studies could be applied. At this stage, several papers describing the method were located through contact with academics known to have utilised the method ${ }^{12,14-16}$. These suggested differing methods.

\section{Stakeholder involvement}

Developed originally as a $\mathrm{PhD}$ thesis ${ }^{17}$, this review was advised by a group of academics with an interest in framework synthesis methods. They comprised cosupervisors, external advisors and colleagues. Interim findings from the thesis were also presented at international conferences ${ }^{18-20}$ and feedback sought.

\section{Searching}

A purposive search strategy was conducted in order to identify research that would address the review's research question and scope ${ }^{21}$, key papers were identified from colleagues, those used in other systematic reviews, and a Google Scholar search using the phrase 'framework synthesis'. These scoping papers were used to derive the research questions developed for the $\mathrm{PhD}$ proposal. Thesaurus specific terms for 'framework synthesis' were not found. Full searching using free text terms were undertaken in ASSIA, PsycInfo, PubMed, and Web of Science. In addition, reference lists of included studies were searched, and key experts contacted. Searches were conducted from database inception up to 1 January 2015, with a search update undertaken to include references up to 31 December 2015. No language limits were set on the searches. These methods were undertaken as recommended in current research synthesis guidance ${ }^{22,23}$.

\section{Inclusion screening}

To be consistent and transparent in assessing all retrieved references, each was screened using previously determined exclusion criteria based on the research 
questions. First, in order to be included in synthesis, reports screened on title and abstract had to:

- specifically indicate the use of 'framework synthesis'; and

- be relevant to health care, health policy or public health.

The full text reports of references meeting both of these criteria were retrieved and screened again. At this stage, reports had to also:

- describe framework synthesis as a synthesis method; and

- provide textual descriptive data from authors that reflected on its use in some way.

\subsection{Framework selection}

Familiarisation with the relevant literature did not identify an existing suitable conceptual framework; thus a conceptual framework of key issues was derived from discussion papers identified in the scoping searches undertaken for writing the $\mathrm{PhD}$ proposal, from the researcher's knowledge of qualitative research methods, and from standard data extraction tools developed over several years of systematic reviewing at the EPPI-Centre ${ }^{5}$. These sources indicated that framework synthesis was likely to vary according to a range of elements:

- the aims of the review in which it was used;

- the stages of framework synthesis used;

- where in the systematic review process the framework was applied;

- the reflections authors make on its use, relevance or applicability;

- the strengths and/or limitations of the method;

- what authors infer from using the method; and

- whether a deductive or inductive use of framework synthesis was described or could be inferred.

These elements became the initial conceptual framework for this review.

\section{Data extraction}

Data were extracted using a coding tool, developed from the review's research questions and the conceptual framework described above. Any characteristics not addressed by initial codes were added to the framework and applied to all included reports. The final coding tool is presented in Appendix 1.

Synthesis and quality appraisal

At the synthesis stage, characteristics of included studies were grouped into categories and themes derived directly from those data. Themes were examined in light of the original research questions, the wider research literature and the context in which the review was originally undertaken. Overarching themes were then derived which became the 'framework synthesis'. 
The data relevant to this review, whether drawn from substantive systematic reviews or methodological papers, were expected to be drawn from discursive text that reflected and interpreted the use of framework synthesis. Thus, traditional quality assessment of included studies normally undertaken in a systematic review of health interventions was not considered appropriate. Instead, critical consideration of each argument was undertaken by reflecting on the content, weight and fit of arguments against each other and in relation to theory development ${ }^{24}$.

Quality assurance of the review

As part of quality assurance, an Information Scientist informed the development of literature searches. Two reviewers undertook screening, with any references identified by either reviewer included for full-text retrieval. One reviewer conducted coding and synthesis, with a $10 \%$ random sample of studies crosschecked by a second reviewer. Data integrity and analysis were maintained and conducted by using EPPI-Reviewer software ${ }^{8}$. 


\section{RESULTS}

\subsection{Indexing}

Searches identified 217 citations, of which 67 were potentially relevant on title and abstract. Retrieval and screening of full text reports identified 43 publications which met the inclusion criteria. These described 37 different reviews or methodological papers, which will be referred to collectively as 'reports'. This flow of reports through the review is illustrated below in Figure 2.

Figure 2. Flow of reports through the review process

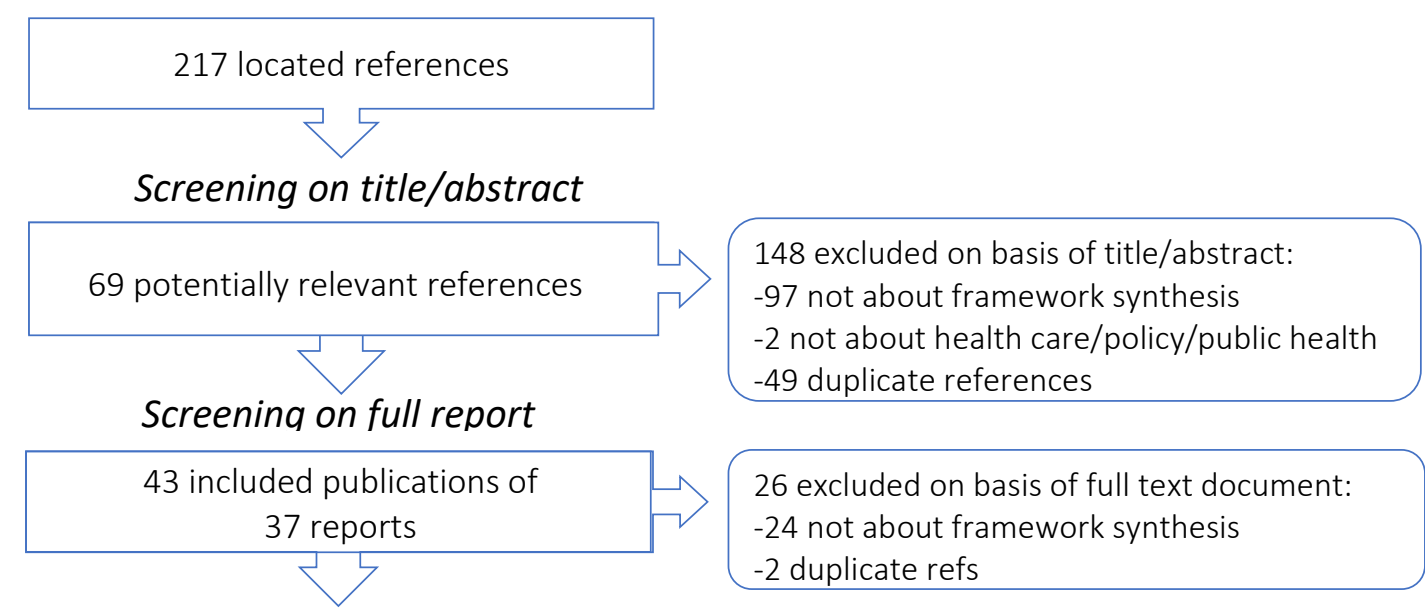

Data extraction / Synthesis

The main characteristics of included reports are provided in Appendix 2. Using the framework described on p.8, reports were examined in further detail to understand why and how framework synthesis was utilised or recommended.

Using the a priori conceptual framework, included reviews and methodological papers were next examined for their contextual, situational, conceptual and process elements.

\section{Contextual elements of reports}

The aims and purposes of each included report were considered contextual elements. From its inception, framework synthesis has been used for both clinically-focused qualitative evidence synthesis and for policy-focused mixed methods evidence synthesis, with concurrent efforts to place it as a method. The 37 included reports presented framework synthesis in three different ways. Most $(n=28)$ simply applied the method to examine a health issue, by seeking to understand the views, perspectives and experiences of patients or clinicians by examining the qualitative research that privileged these views. Four reports were instructive in nature, describing the utility and method of framework synthesis by using an illustrative example $\mathrm{e}^{12,15,16,25}$. Other reports situated framework synthesis 
within a range of evidence synthesis methods ${ }^{5,10,26-28}$. Applied examples of the method first appeared in $2004^{29,30}$. Framework synthesis has since been used in both qualitative and mixed methods evidence syntheses ${ }^{14,30}$.

\section{Situational elements}

The conditions under which framework synthesis was reported to be useful were grouped as situational elements. Several authors suggested that framework synthesis is a highly structured or systematic approach for both organising and interpreting data ${ }^{12,26,27,30-34}$. It was reported to be useful for time-limited projects, with specific questions addressing well defined priority issues, sometimes identified by public and professional stakeholders, and explicitly incorporated into the analysis ${ }^{15,25,30}$. However, it was also noted that framework synthesis allows both the coding of data into pre-defined categories and for new categories to emerge ${ }^{25,35-37}$. Authors also claimed it to be useful both where data is thin or largely descriptive in nature as well as where it allows thematic deductive analysis ${ }^{38,39}$. Others described it as useful for exploring theory, interrogating relationships and developing conceptual models ${ }^{28}$. Such differing claims were made elsewhere: some suggested that framework synthesis fosters the sharing of emerging data between researchers ${ }^{32,33}$, while others note it allows replicability ${ }^{34}$.

\section{Conceptual elements}

Authors also varied in their description of the theoretical or conceptual elements of framework synthesis. The epistemology underlying framework synthesis was rarely described across the set of studies; those that did report it described it as a realist method ${ }^{26-28,40}$. Elsewhere, it was described as an interpretive approach ${ }^{41}$ or used where the topic indicated 'a domain in which realist-positivist and constructivist-interpretive ontologies must cohabit.' ${ }^{42}$ (p.4).

The majority of reports described framework synthesis as both a deductive and inductive method. However, a few identified it as a deductive only method whilst simultaneously suggesting that it was iterative in nature ${ }^{12,27,28,39}$. Others described the use of iteration, without further defining a deductive or inductive approach $37,43-45$

Many included reports reflected on theory development within framework synthesis $10,12,14,16,25,34,36,39,40,44-51$. Fewer utilised framework synthesis to understand or explain what was happening within an intervention ${ }^{15,27,32,37,43,52}$. It was also argued that framework synthesis might allow both the development, exploration and testing of theory ${ }^{6,10,15}$. The extent of theory development varied across the reports. Framework synthesis was deemed useful where a relevant conceptual framework already existed ${ }^{46,50}$. Elsewhere, the method informed theory development by: undertaking thematic analysis without generating new theory (by using a previously existing theory); by fostering simple taxonomy 
development which sometimes led to theorising causal processes ${ }^{47,48,51}$; and through searching, assessing and potentially amalgamating theories to construct an a priori theoretical framework ${ }^{16}$.

\section{Process elements}

Across the included reports, differences were noted in the way that authors reported the process of conducting framework synthesis. For example, half of the applied reviews selected an identifiable previously developed framework during the familiarisation stage $\mathrm{s}^{37-42,44,46,47,49-53}$. However, one of these selected a previously developed framework after studies were coded ${ }^{40}$. Another applied review $^{31}$ amalgamated multiple existing frameworks, a method supported more recently ${ }^{12,15,16}$. Many reviews did not select any one pre-existing conceptual framework; instead, an a priori framework was selected based on researchers' experiences of public involvement and the data identified in the systematic search for and appraisal of studies ${ }^{14,30,35,36,45,54-56}$. Included studies were sometimes used to develop their frameworks ${ }^{32,33,43,57}$ or to check the credibility and transferability of their emerging framework through subsequent public and professional stakeholder consultations ${ }^{14,35,54,55}$.

The stages of indexing and charting were similarly described across reviews. However, framework methods of mapping and interpretation varied: as a communication tool to set the scope of the review ${ }^{14,25}$; to foster stakeholder engagement throughout the research process ${ }^{14}$; to map and interpret findings across and for a range of stakeholders ${ }^{10,26,28,50}$; to make recommendations for future research and policy $26,28,47$; and to encourage future stakeholder engagement ${ }^{49}$. It is striking that, considering that almost all reviews sought research on the perspectives and experiences of patients or caregivers, few utilised these same stakeholders in the review's design or in interpretation of the findings $\mathrm{s}^{6,14,35,44,45,48,54,55}$.

While quality assessment was routinely conducted, the findings were used in different ways. All but two of the applied reviews undertook quality assessment, using a range of established tools. Most of these simply presented percentages of the included studies across the dataset that met each quality assessment criterion with little further consideration of their impact on review findings. Three applied and illustrative reports did reflect further on the importance of quality assessment and its impact on synthesis, by presenting summed individual quality criteria across the dataset ${ }^{40}$, or suggested that all studies should be included regardless of study quality and sensitivity analysis undertaken ${ }^{12,16,40}$. Illustrative and situational reports ranged in their examination of quality assessment, with some describing or advocating the use of critical appraisal tools ${ }^{12,26}$, weighting by study quality ${ }^{26}$, and looking at dissonance and quality more critically ${ }^{16}$. 
These situational, conceptual and process elements that define framework synthesis suggest that it has been used for both qualitative evidence synthesis and mixed methods research synthesis, however, the rationale for its use is not often described, which may explain contradictory claims about its utility. It has been used to generate, explore and test theory, with variations in the application of framework synthesis processes.

\subsection{Charting}

Charting of the indexed contextual, situational, conceptual and process elements identified three patterns: the type of systematic review being conducted; the ways in which stakeholder perspectives were sought; and the interplay between frameworks and data.

\section{Type of systematic review}

Framework synthesis has been developed through initial use in qualitative evidence syntheses and in more recent mixed methods systematic reviews ${ }^{6,35,42,44,45,49,55}$. In some cases, mixed methods framework synthesis brought together different types of research in order to create a current, comprehensive understanding of a topic ${ }^{14,31,42,45}$; but they also go beyond this to understand effectiveness ${ }^{6,44,54}$.

\section{Methods of engagement}

In contrast to direct public and professional stakeholder engagement, most framework syntheses of qualitative research sought to understand the views, perspectives and experiences of patients or clinicians by examining the qualitative research that privileged these views. Direct stakeholder engagement and involvement in the review process was less often described ${ }^{6,14,35,44,45,54,55}$ and conducted by a research team with an explicit focus on understanding and developing the methods of public engagement in research ${ }^{58}$.

\section{Interplay between frameworks and data}

In qualitative evidence syntheses, framework synthesis is used to interpret data as a means of understanding phenomenon. However, in mixed methods reviews, it is used as an overall approach to both build theory and test data. Framework syntheses has been conducted to understand a wide range of health and health systems issues, each employing an existing conceptual framework. However, they have also been used to build theory from researchers' prior knowledge and from issues identified in the literature, suggesting a broader interpretation of using existing theory and a priori theory selection. This suggests that the method itself is not prescriptive but is evolving, as other qualitative methods have done ${ }^{27}$. 


\subsection{Mapping of concepts from data patterns}

Four main themes were derived from the concepts assessed in the initial conceptual framework and from the resulting patterns charted from these findings, reflecting the ways in which framework synthesis differs across methodological papers:

- The conditions (context, aims and diversity) of reviews;

- The methods of framing;

- The ways in which gaps are assessed across reviews; and

- The epistemological approach underpinning a review.

\section{Theme 1: Context of the review}

The rationale for selecting framework synthesis as a method depends on its context: the circumstances and conditions under which a review is undertaken. Most often framework synthesis has been used to understand participants' views of an aspect of a medical illness or treatment (e.g. treatment burden or participation in care). Urgent need for evidence, theory development/data interpretation, and the nature of the data or analysis have also influenced the decision to use framework synthesis.

\section{Theme 2: Methods of framing}

Framework synthesis can be used to frame the topic and scope of a review, the concepts under study, the synthesis and the knowledge exchange with a range of stakeholders. Whilst following steps outlined by Ritchie and Spencer (1994), descriptions vary about how and when the a priori conceptual framework should be either selected or constructed, and used (i.e. at the beginning, during data extraction and synthesis, and/or for communication). In addition, it was described by most as a valuable method to privilege stakeholder views, in that it enabled stakeholder questions to be addressed, translated research findings for use by stakeholders, and made it easier to embed stakeholders' experiences into future intervention development.

\section{Theme 3: Assessing gaps}

Framework synthesis usefully assesses how well included research fits a selected theory; however, the fit between theory and data is not well-articulated. To ensure that framework synthesis is robust, Carroll et al. (2013) recommended that missing or 'uncomfortable' data should be assessed to evaluate potential gaps between the selected framework and the data ${ }^{16}$. However, this was not consistently reported across reviews that applied framework synthesis. For example, 18 of the 28 applied reviews examined the fit between their included research and the selected conceptual framework (dissonance assessment). Only six reviews examined whether the chosen framework contained elements not addressed by their included research studies (gap analysis). Reviews published before or more recently since the recommendations made by Carroll et al. ${ }^{16}$ have not, perhaps 
unsurprisingly, undertaken these steps. But dissonance assessment and gap analysis may also not be appropriate where theory is being developed more inductively rather than deductively. With respect to assessing gaps in methodological quality, critical assessment of included studies is consistently evidenced, although different tools are used. Consideration of the impact of gaps in study quality on review findings has also been advocated ${ }^{16}$.

\section{Theme 4: Epistemological approach}

While researcher stance was not consistently described, the discussions and reflections across this set of reports about framework synthesis suggest that it is a method in which reality can be known but is also a function of time and place ${ }^{59}$. It was challenging to understand whether authors were trying to test, explore, or generate theory ${ }^{10}$ due to the gaps in reporting of underlying theoretical assumptions and differences in the selection of a priori frameworks. Framework synthesis is alternately described as useful for developing theory and examining causal processes ${ }^{47}$, better for exploring causality than addressing theory ${ }^{60}$, or more useful when conceptual understanding is not clear and data need contextualising ${ }^{16,28,49}$, or to exercise judgmental rationality (i.e. the ability to decide rationally on the merit of a theory) ${ }^{61}$. These contrasting insights into the underpinning ontology and epistemology used across reports suggest that framework synthesis is an approach involving varying degrees of exploration and testing of theory, dependent on the review's context, aims and research question, which also imbue the method with some interpretive qualities. This blurring of epistemological distinctions when categorising the method suggest that it could also be a method of 'selective eclecticism' ${ }^{62}$, where synthesis methods and their underlying paradigms are mixed in order to best suit the context and research question under study.

\subsection{Interpretation}

This review of previous use and reflections on framework synthesis suggests an interaction exists between the context of the reviews, the methods of framing, how gaps were assessed, and epistemological considerations was identified. This interaction is illustrated in Figure 3 below. 
Figure 3. Final framework synthesis

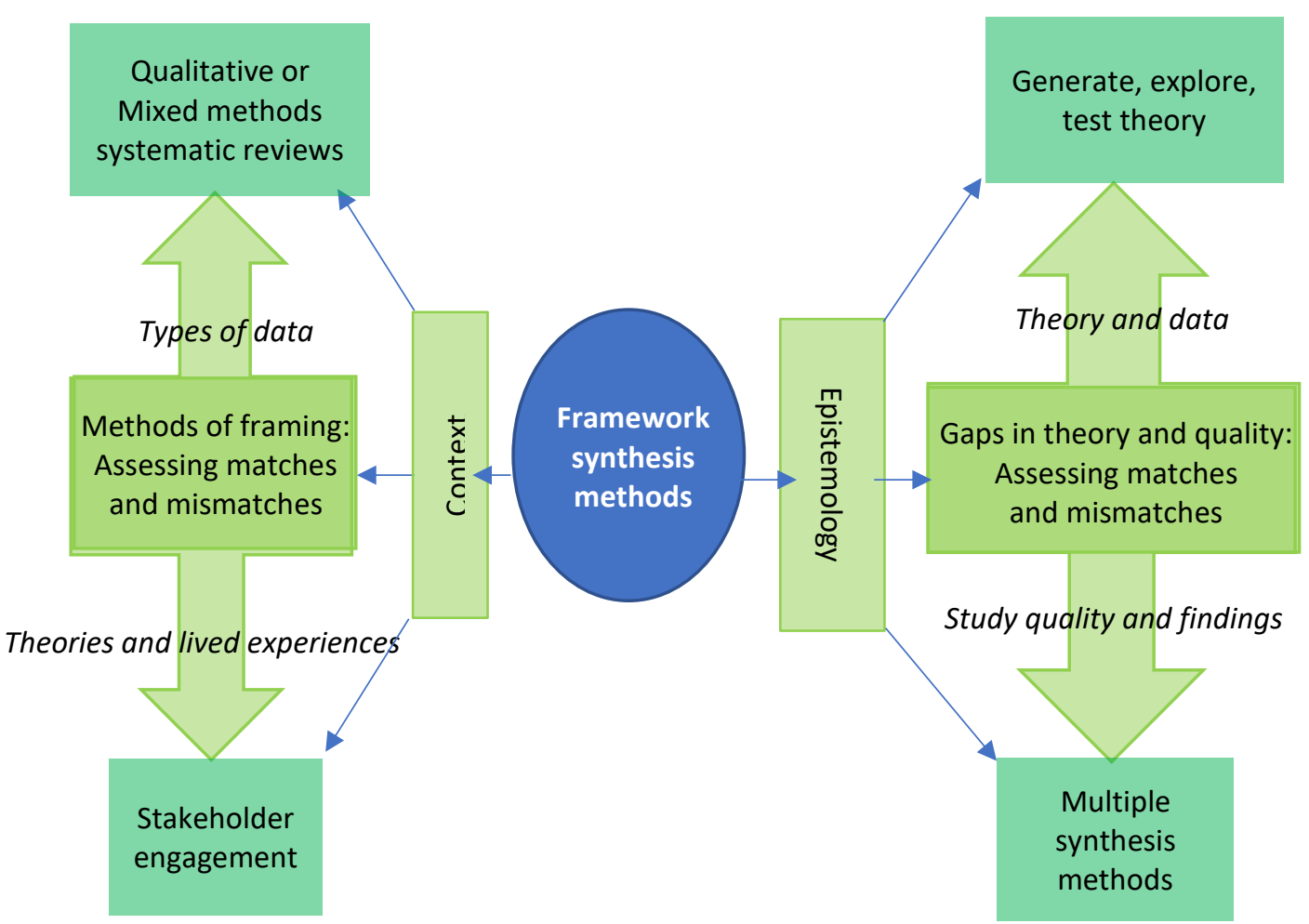

Framework synthesis methods are derived from the context in which they are undertaken (illustrated on the left-hand side of the diagram). The context influences how knowledge is framed: both through the types of data that influence the review design and by how theories and lived experiences are considered (through public and professional stakeholder engagement throughout the review process). Framework synthesis methods are also derived from epistemology (shown on the right-hand side of the diagram). Underlying approaches to theory and data use influence whether theory is generated, explored or tested and whether approaches to assessing study quality and using findings drive the synthesis methods used.

\section{DISCUSSION AND CONCLUSIONS}

\subsection{Addressing the research questions}

This systematic review sought to answer several questions about the use of framework synthesis:

1. How do methods of framework synthesis compare within research synthesis? 
Framework synthesis has been described and utilised in health care evidence synthesis in a variety of ways. While some have sought to synthesise one type of research evidence in order to 'frame' those perspectives against a previously existing theory ${ }^{43,46,47,50,51}$, others have synthesised multiple types of research or other evidence separately and then brought these findings together into a third synthesis, using different types of synthesis methods $6,14,35,44,49,54,55$. These 'mixed studies' and 'mixed sources' reviews seek to address broad and complex policy questions that go beyond questions of 'is it effective?' and 'what are people's experiences?' to include broader issues of how something might work and under what circumstances ${ }^{5}$. In addition, framework synthesis provided a mechanism conducive to transdisciplinary stakeholder engagement with its structure for organising theory and its transparency for clear communication to facilitate discussion with a range of stakeholders.

2. Where is framework synthesis located within the context of a range of research synthesis methods?

Within the ever-widening spectrum of research synthesis methods, framework synthesis appears to be a method that is positioned 'in the middle' in terms of its a priori and emergent reasoning and iteration to generate, explore and test theory using heterogeneous data. In general, research synthesis methods can be thought of as lying along a continuum of theory generation, exploration or testing, as illustrated in Figure 4 below.

Figure 4: 'Dimensions of difference' in approaches to synthesis

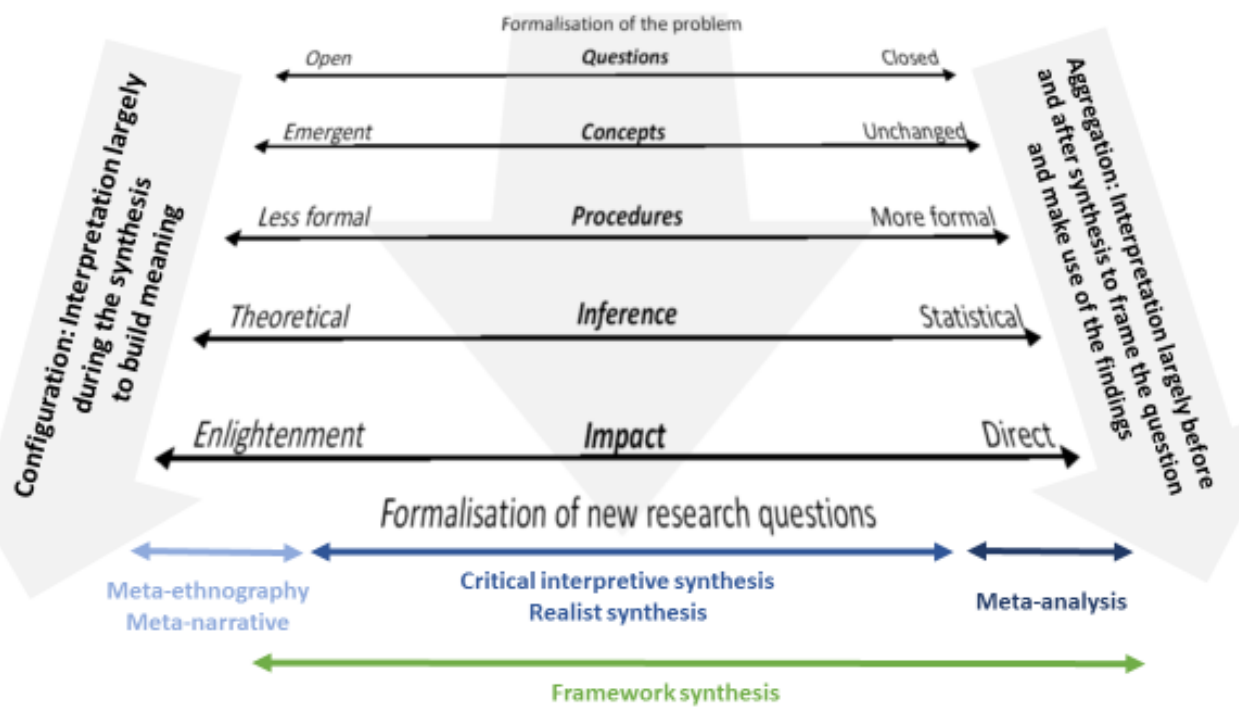

(Adapted from Thomas et al. 2017:69) 
Whilst sitting along a continuum, meta-ethnography and meta-narrative approaches sit within the context of generating theory. Critical interpretive synthesis and realist synthesis are more suited to explore theory, while metaanalysis acts to test theory. All of these approaches can overlap in terms of the extent to which theory is generated, explored or tested. However, framework synthesis spans the entire continuum, which methods such as meta-ethnography, meta-narrative and meta-analysis cannot do. It can be argued that framework synthesis allows enough interpretive creativity for it to move between critical and scientific realism ${ }^{63}$ and findings from some included reports suggest that this may be dependent on the extent to which stakeholders' views are employed either as participants in the research process or as the phenomenon under study. This suggests it is a useful alternative to realist synthesis ${ }^{7}$ and critical interpretive synthesis ${ }^{7,64}$. However, in order to ensure the review findings are as robust and relevant as possible to end users, it is important to clarify which stakeholders will be involved in the review, and in what ways, prior to selecting a method of synthesis. Differences are also suggested between these framework syntheses and realist synthesis regarding the involvement of public stakeholders, as it has been suggested that the role of public stakeholders has not been clarified in realist review methods guidance ${ }^{65}$.

3. What problems are addressed by framework synthesis and not by other methods?

Unclear reporting of synthesis methods is a challenge in qualitative research synthesis ${ }^{66}$. Framework synthesis may help to make reporting of methods more transparent. Readers can see clearly the original conceptual framework, the themes that are derived from the data populating that framework, and how the themes are translated back into the original framework to further develop that theory.

The results of this review suggest that the philosophical stance of a study should fit the research question, which itself is derived from both the context in which the phenomenon under study is occurring and from the researcher's own preferences ${ }^{48,67}$. Further, clearly communicating these will help readers to understand and interpret the review's methods and findings. Framework synthesis offers a method of combining data that allows both aggregation and configuration of findings fit to purpose and context of the review. This suggests a 'selective eclecticism' approach that could address calls for a paradigm shift in research methods ${ }^{48,62,68}$.

Framework syntheses that utilise mixed methods benefit from, and potentially strengthen, stakeholder engagement in research. Comparison of the literature on framework synthesis indicated that most reviews sought to synthesise one type of research evidence (i.e. qualitative research of participants' experiences or case 
studies) in order to 'frame' those perspectives against a previously existing theory. Other reviews built conceptual frameworks from the views of lay people (i.e. their expressed barriers and facilitators), discussing the frameworks and the research they frame with review stakeholders, and in some cases applied multiple research synthesis methods (e.g. QCA, meta-regression, constant comparative analysis) within them $6,14,35,36,44,45,51,54,55$. These innovations made it easier to address stakeholder priorities and to draw on conclusions and recommendations relevant to public stakeholders. As such, these are transdisciplinary systematic reviews designed for decision making because they are framed not by academic disciplines or methodologies but by concepts that transcend them ${ }^{69-71}$. Framework synthesis thus provides an approach that helps to advance the use of qualitative evidence synthesis in practice/policy whilst facilitating public involvement in research.

\subsection{Potential limitations}

Some potential limitations were identified to the methodological approach of this review. Searches for relevant literature were conducted up to 2015. While these were considered current for the publication of the $\mathrm{PhD}$, it has been suggested that systematic reviews should be ideally updated to one year before publication for interventions ${ }^{72}$. Given that this review used rigorous, transparent, systematic methods and more recently published reviews and guidance have not suggested newer uses of framework synthesis ${ }^{73-75}$, it is likely that the data underpinning these findings are representative of the method's current use ${ }^{76}$.

Using framework synthesis to undertake a systematic review about framework synthesis may appear to be somewhat overcomplicated. However, synthesis should be guided by a review's purpose and context ${ }^{8}$. This review aimed to use an identified (although nascent) conceptual framework in order to build a more comprehensive understanding of the use and utility of framework synthesis. It was undertaken to further develop knowledge of the method and to provide a structure in which the body of knowledge on framework synthesis methods can be understood. These aims and objectives suggested a need for an approach that allowed for some interpretation of data in order to configure a new understanding of the method - something that framework synthesis is well-suited to address.

\subsection{Future research implications}

In order to allow readers to assess the fit between the synthesis method and the end use of the review, future use of framework synthesis should include descriptions of researchers' stance and/or the ontological and epistemological stance underpinning the review. To make clear the process of framework selection, researchers could provide more detail on how the initial framework was identified and adapted for use (if this occurred), as noted by others ${ }^{15,16}$. The initial and final conceptual frameworks should be included for readers to assess how the data changes the theory. Finally, it will benefit understanding about stakeholder 
contributions to the review process and to specific stages of framework synthesis if there is more careful documentation of public stakeholders' role in shaping the conceptual framework as it develops through the review.

[4964 words]

\section{HIGHLIGHTS}

Framework synthesis is one systematic review method employed to address health care practice and policy. Adapted from framework analysis methods, it has been used increasingly in qualitative and mixed-method systematic reviews. This paper demonstrates two key approaches to its use: one that utilises mixed methods, in order to accommodate research from across academic disciplines and/or policy sectors, to construct, explore and/or test a conceptual framework (often in discussion with public and other stakeholders); and a 'best-fit' approach that borrows a framework from a related area to initiate qualitative evidence synthesis within a narrower disciplinary or policy scope. Its utility is demonstrated in facilitating mixed methods reviews, using diverse data types and synthesis methods in order to generate, explore and/or test theory in collaboration with stakeholders. Framework synthesis provides a flexible research synthesis approach that can meet the multiple conditions and epistemologies arising from health policy and practice issues. 


\section{REFERENCES}

1. Lavis J, Davies H, Oxman A, Denis JL, Golden-Biddle K, Ferlie E. Towards systematic reviews that inform health care management and policy-making. Journal of Health Services Research \& Policy. 2005;10(Suppl 1):35-48.

2. Oakley A, Gough D, Oliver S, Thomas J. The politics of evidence and methodology: lessons from the EPPI-Centre. Evidence and Policy. 2005;1(1):5-32.

3. Lavis JN. How can we support the use of systematic reviews in policymaking? PLoS Medicine. 2009;6(11).

4. Petticrew M, Roberts H. Systematic reviews in the social sciences: A practical guide. London: John Wiley \& Sons; 2008.

5. Gough D, Oliver S, Thomas J. An introduction to systematic reviews. 2 ed. London UK: Sage; 2017.

6. O'Mara-Eves A, Brunton G, McDaid D, et al. Community engagement to reduce inequalities in health: a systematic review, meta-analysis and economic analysis. . Public Health Research. 2013;1(4):1-528.

7. Pawson R, Greenhalgh T, Harvey G, Walshe K. Realist synthesis: an introduction. Manchester: University of Manchester;2004.

8. Thomas J, Harden A, Newman M. Synthesis: combining results systematically and appropriately. In: Gough D, Oliver S, Thomas J, eds. An introduction to systematic reviews. London: Sage; 2012:178-226.

9. Booth A, Noyes J, Flemming K, et al. Guidance on choosing qualitative evidence synthesis methods for use in health technology assessments of complex interventions. Bremen DE: University of Bremen;2016.

10. Thomas J, O'Mara-Eves A, Harden A, Newman M. Synthesis methods for combining and configuring textual or mixed methods data. In: Gough D, Oliver S, Thomas J, eds. An introduction to systematic reviews. 2 ed. London: Sage; 2017:211-250.

11. Ritchie J, Spencer L. Qualitative data analysis for applied policy research. In: Bryman A, Burgess RG, eds. Analyzing qualitative data. London: Routledge; 1994:173-194.

12. Carroll C, Booth A, Cooper K. A worked example of 'best fit' framework synthesis: a systematic review of views concerning the taking of some potential chemopreventive agents. BMC Medical Research Methodology. 2011;11(1):29.

13. Ritchie J, Lewis J, McNaughton Nicholls C, Ormston R. Qualitative research practice: a guide for social science students and researchers. London: Sage; 2014.

14. Oliver SR, Rees RW, Clarke-Jones L, et al. A multidimensional conceptual framework for analysing public involvement in health services research. Health Expectations. 2008;11(1):72-84.

15. Booth A, Carroll C. How to build up the actionable knowledge base: the role of 'best fit' framework synthesis for studies of improvement in healthcare. BMJ Quality \& Safety. 2015;24(11):700-708.

16. Carroll C, Booth A, Leaviss J, Rick J. "Best fit" framework synthesis: refining the method. BMC Medical Research Methodology. 2013;13(1):37. 
17. Brunton G. Innovation in systematic review methods: successive developments in framework synthesis. [Doctor of Philosophy]. London UK: Department of Social Science, University College London; 2017.

18. Brunton G, Oliver S, Thomas J. Applying framework synthesis to understand complexity in systematic reviews: A systematic review of methods. Oral presentation presented at Cochrane Colloquium; October 2015, 2015; Vienna, Austria.

19. Brunton G, Llewellyn A, Sutcliffe K, et al. Use of framework synthesis to prioritise systematic review topics among multiple stakeholders: a descriptive case study. Oral presentation presented at Cochrane Colloquium; October 2015, 2015; Vienna, Austria.

20. Brunton G. Innovations in framework synthesis. Oral presentation presented at Global Evidence Summit, (Cochrane \& Campbell Collaboration); September 2017, 2017; Cape Town, South Africa.

21. Brunton G, Stansfield C, Caird J. Finding relevant studies. In: Gough D OS, Thomas J (eds), ed. An introduction to systematic reviews. 2 ed. London: Sage; 2017:93-122.

22. Chandler J, Churchill R, Higgins J, Lasserson T, Tovey D.

Methodological standards for the conduct of new Cochrane Intervention Reviews, Version 2.3. 2013; http://editorialunit.cochrane.org/sites/editorialunit.cochrane.org/files/uploads/MECIR_conduct_standards_2.3_021220 13.pdf. Accessed 29 March 2016.

23. Moher D, Liberati A, Tetzlaff J, D.G. A. Preferred reporting items for systematic reviews and meta-analyses: the PRISMA statement. Annals of Internal Medicine. 2009;151(4):264-269.

24. Garside R. Should we appraise the quality of qualitative research reports for systematic reviews, and if so, how? Innovation: The European Journal of Social Science Research. 2014;27(1):67-79.

25. Dixon-Woods M. Using framework-based synthesis for conducting reviews of qualitative studies. BMC Medicine. 2011;9(1):39.

26. Barnett-Page E, Thomas J. Methods for the synthesis of qualitative research: a critical review. BMC Medical Research Methodology. 2009;9:59.

27. Paterson B. "It looks great but how do I know if it fits?": an introduction to meta-synthesis research. In: Hannes K, Lockwood C, eds. Synthesizing qualitative research: choosing the right approach: John Wiley \& Sons; 2012:1-20.

28. Petticrew M, Rehfuess E, Noyes J, et al. Synthesizing evidence on complex interventions: how meta-analytical, qualitative, and mixedmethod approaches can contribute. Journal of Clinical Epidemiology. 2013;66(11):1230-1243.

29. Lloyd Jones M. Application of systematic review methods to qualitative research: practical issues. Journal of Advanced Nursing. 2004;48(3):271278.

30. Lloyd Jones M. Role development and effective practice in specialist and advance practice roles in acute hospital settings. Journal of Advanced Nursing. 2005;49(2):191-209. 
31. Ram MB, Campling N, Grocott P, Weir H. A methodology for a structured survey of the healthcare literature related to medical device users. Evaluation. 2008;14(1):49-73.

32. Tierney S, Mamas M, Skelton D, et al. What can we learn from patients with heart failure about exercise adherence? A systematic review of qualitative papers. Health psychology : official journal of the Division of Health Psychology, American Psychological Association.

2011;30(4):401-410.

33. Tierney S, McGlone C, Furber C. What can qualitative studies tell us about the experiences of women who are pregnant that have an eating disorder? Midwifery. 2013;29(5):542-549.

34. Watson R, Parr JR, Joyce C, May C, Le Couteur AS. Models of transitional care for young people with complex health needs: a scoping review. Child: care, health and development. 2011;37(6):780-791.

35. Brunton G, Caird J, Stokes G, et al. Community engagement for health via coalitions, collaborations and partnerships: a systematic review. London UK: EPPI-Centre, Social Science Research Unit, UCL Institute of Education; 2015 2015b. 978-1-907345-74-6.

36. Connell J, Brazier J, O'Cathain A, Lloyd-Jones M, Paisley S. Quality of life of people with mental health problems: a synthesis of qualitative research. Health and Quality of Life Outcomes. 2012;10.

37. McEvoy R, Ballini L, Maltoni S, O'Donnell CA, Mair FS, Macfarlane A. A qualitative systematic review of studies using the normalization process theory to research implementation processes. Implementation science : IS. 2014;9:2.

38. Glenton C, Colvin CJ, Carlsen B, et al. Barriers and facilitators to the implementation of lay health worker programmes to improve access to maternal and child health: qualitative evidence synthesis. Wiley; 2013/10// 2013.

39. Walt G, Gilson L. Can frameworks inform knowledge about health policy processes? Reviewing health policy papers on agenda setting and testing them against a specific priority-setting framework. Health Policy and Planning. 2014;29 Suppl 3:iii6-iii22.

40. Luckett T, Davidson Patricia M, Green A, Boyle F, Stubbs J, Lovell M. Assessment and management of adult cancer pain: a systematic review and synthesis of recent qualitative studies aimed at developing insights for managing barriers and optimizing facilitators within a comprehensive framework of patient care. Journal of Pain and Symptom Management. 2013;46(2):229-253.

41. Davies SL, Goodman C, Bunn F, et al. A systematic review of integrated working between care homes and health care services. BMC health services research. 2011;11:320.

42. Rimstad R, Braut Geir S. Literature Review on Medical Incident Command. Prehospital and Disaster Medicine. 2015;30(2):205-215.

43. Ingram JC, Deave T, Towner E, Errington G, Kay B, Kendrick D. Identifying facilitators and barriers for home injury prevention interventions for pre-school children: a systematic review of the quantitative literature. Health Education Research. 2012;27(2):258-268.

44. Noyes J, Brenner M, Fox P, Guerin A. Reconceptualizing children's complex discharge with health systems theory: novel integrative review 
with embedded expert consultation and theory development. Journal of Advanced Nursing. 2014;70(5):975-996.

45. Wilman E, Megone C, Oliver S, Duley L, Gyte G, Wright JM. The ethical issues regarding consent to clinical trials with pre-term or sick neonates: a systematic review (framework synthesis) of the empirical research. Trials. 2015;16:502.

46. Fishwick C, McGregor M, Drury M, Webster J, Rick J, Carroll C. British Occupational Health Research Foundation (BOHRF) smoking cessation review. Buxton UK: British Occupational Research Foundation;2012.

47. Gallacher K, Morrison D, Jani B, et al. Uncovering treatment burden as a key concept for stroke care: a systematic review of qualitative research. PLoS Medicine. 2013;10(6):e1001473.

48. Gough D, Thomas J, Oliver S. Clarifying differences between review designs and methods. Systematic Reviews. 2012;1:28-36.

49. Kruijsen-Terpstra AJ, Ketelaar M, Boeije H, et al. Parents' experiences with physical and occupational therapy for their young child with cerebral palsy: a mixed studies review. Child Care Health and Development. 2014;40(6):787-796.

50. Mytton J, Ingram J, Manns S, Thomas J. Facilitators and barriers to engagement in parenting programs: a qualitative systematic review. Health Education \& Behavior. 2013;41(2):127-137.

51. Demain S, Goncalves A-C, Areia C, et al. Living with, managing and minimising treatment burden in long term conditions: A systematic review of qualitative research. PloS One. 2015;10(5):e0125457.

52. Sohanpal R, Steed L, Mars T, Taylor SJC. Understanding patient participation behaviour in studies of COPD support programmes such as pulmonary rehabilitation and self-management: a qualitative synthesis with application of theory. NPJ Primary Care Respiratory Medicine. 2015;25:1-15.

53. Dearden E, Mellanby E, Cameron H, Harden J. Which non-technical skills do junior doctors require to prescribe safely? A systematic review. British Journal of Clinical Pharmacology. 2015;80(6):1303-1314.

54. Brunton G, Oliver S, Oliver K, Lorenc T. A synthesis of research addressing children's, young people's and parents' views of walking and cycling for transport. London UK: EPPI-Centre, Social Science Research Unit; 2006/11// 2006. WOS:000334890100001.

55. Brunton G, Caird J, Sutcliffe K, et al. Depression, anxiety, pain and quality of life in people living with chronic hepatitis C: a systematic review and meta-analysis. London UK: EPPI-Centre, Social Science Research Unit; 2014 2014. 978-1-907345-73-9.

56. Petersen P, Godtfredsen J, Boysen G, Andersen E, Andersen Bor. Placebo-controlled, randomised trial of warfarin and aspirin for prevention of thromboembolic complications in chronic atrial fibrillation. Lancet. 1989;333(8631):175-179.

57. Horne M, Tierney S. What are the barriers and facilitators to exercise and physical activity uptake and adherence among South Asian older adults: a systematic review of qualitative studies. Preventive medicine. 2012;55(4):276-284. 
58. EPPI-Centre. Participative research and policy. [[Online]]. 2016; http://eppi.ioe.ac.uk/cms/Default.aspx?tabid=428. Accessed 7 April, 2018.

59. Sayer A. Realism and social science.. London: Sage; 2000.

60. Dixon-Woods M, Agarwal S, Jones D, Young B, Sutton A. Synthesising qualitative and quantitative evidence: a review of possible methods. Journal of Health Services Research \& Policy. 2005;10(1):45 - 53.

61. Bhaskar R. From science to emancipation: alienation and the actuality of enlightenment. London: Sage; 2002.

62. Suri H. Epistemological pluralism in research synthesis methods. International Journal of Qualitative Studies in Education. 2013;26(7):889-911.

63. Chakravartty A. Scientific realism. Stanford encyclopedia of philosophy (Online). . 2011; http://plato.stanford.edu/entries/scientific-realism/. Accessed 31 March 2016.

64. Dixon-Woods M, Cavers D, Agarwal S, et al. Conducting a critical interpretive synthesis of the literature on access to healthcare by vulnerable groups. BMC Medical Research Methodology. 2006;6(1).

65. Harris J, Croot L, Thompson J, Springett J. How stakeholder participation can contribute to systematic reviews of complex interventions. Journal of Epidemiology and Community Health. 2015;70:207-214.

66. Tong A, Flemming K, McInnes E, Oliver S, Craig J. Enhancing transparency in reporting the synthesis of qualitative research: ENTREQ. BMC Medical Research Methodology. 2012;12(1):181.

67. Green J, Thorogood N. Qualitative methods for health research. London: Sage; 2014.

68. Sandelowski M, Voils CI, Leeman J, Crandell JL. Mapping the mixed methods-mixed research synthesis terrain. Journal of Mixed Methods Research. 2012;6(4):317-331.

69. Mollinga PP. Boundary work and the complexity of natural resources management. Crop Science. 2010;50(Suppl 1):S1-S9.

70. Hollingsworth JR. The decline of scientific communication within and across academic disciplines. Policy Studies Journal. 1986;14(3):422-428.

71. Krishnan A. What are academic disciplines. Southampton UK: University of Southampton, NCRM E Prints Repository 2009.

72. Higgins JP, Lasserson T, Chandler J, Tovey D, Churchill R. Standards for the conduct and reporting of new Cochrane Intervention Reviews, reporting of protocols and the planning, conduct and reporting of updates. 2016.

73. Jacobs P, MacMahon K, Quayle E. Transition from school to adult services for young people with severe or profound intellectual disability: A systematic review utilizing framework synthesis. Journal of Applied Research in Intellectual Disabilities. 2018.

74. Rehfuess E, Booth A, Brereton L, et al. Towards a taxonomy of logic models in systematic reviews and health technology assessments: a priori, staged and iterative approaches. Research Synthesis Methods. 2017.

75. Rabeea'h WA, Hendry M, Booth A, et al. Intervention Now to Eliminate Repeat Unintended Pregnancy in Teenagers (INTERUPT): a systematic 
review of intervention effectiveness and cost-effectiveness, and qualitative and realist synthesis of implementation factors and user engagement. BMC medicine. 2017;15(1):155.

76. Garner P, Hopewell S, Chandler J, et al. When and how to update systematic reviews: consensus and checklist. BMJ. 2016;354:i3507. 


\section{Appendix 1. Coding tool}

Guidance information appears in [italicised brackets]

\section{Year of publication}

[Indicate using relevant year]

\section{Aims of report described?}

[Describe as stated by authors in info box]

\section{Which Evidence Synthesis used FS}

\section{QES}

MMRS [Use this code if the review utilised framework synthesis to draw together findings from multiple types of data and/or multiple analyses. These could include synthesis of any of: data from qualitative and quantitative studies; findings from QES and meta-analysis; data from research sources and other sources (e.g. stakeholders)]

Not relevant [i.e. no evidence synthesis; use this for situated papers]

\section{How do authors characterise the method?}

[i.e., did they list the steps as described by Ritchie and Spencer? Or if they didn't, did they justify why and how they deviated?]

\section{Rationale or reason for using it}

\section{Cited whom?}

\section{How do the authors contextualise the method?}

[Did authors apply framework synthesis to one stage of the review (e.g. analysis stage only), or did they describe its use in setting the research question, community engagement, etc.? OR Did authors discuss the use of framework synthesis as a method of systematic reviews?]

Applied FS [A paper that primarily reports substantive findings from a systematic review that used framework synthesis. May contain some reflection on the use of the method.]

Illustrated FS [A paper that primarily focuses on describing and reflecting on the use of framework synthesis alone. May use a systematic review to illustrate its application.]

Situated FS [A paper that primarily situates framework synthesis within a wider methodology.]

\section{Reflections on the FS Method}

No reflection of methods described [These are FT EXC2s: systematic reviews about framework synthesis that didn't reflect on their methods; this will be used to show how many SRs are using FS and to look for similarities / differences in aims] 
What general reflections on the method do authors make? [For example, do authors analyse what framework synthesis is or what it provides?]

Strengths of the method? [Did authors reflect on the strengths of using framework synthesis?]

Limitations of the method? [Did the authors reflect on any limitations in using framework synthesis methods?]

Were any future research/methods recommended by authors? [Did authors describe any methods work that needs to be addressed as a result of conducting this study? Did authors provide any 'tips' for those wanting to apply FS in future?] What do authors infer from using the method? [What conclusions do authors arrive at (e.g. do they appear to claim their work has broadened a theory or created a new one)? This isn't about what they think of framework synthesis - it's about finding clues to whether they applied deductive or inductive reasoning.]

\section{Deductive or Inductive?}

Deductive (specify) [Stated or inferred? Deductive='theory testing' - starts with a theory; observations are then sought to support or refute the theory]

Inductive (specify) [Stated or inferred? Inductive $=$ 'theory building' $=$ moves from specific observations to broader generalisations or theories; NOTE can not ever 'prove' a theory is correct with inductive logic, only that it is 'probable'.]

Both Deductive and Inductive (specify)

Deduction/Induction Not described

\section{Discussion of iteration?}

[Do authors discuss any iteration (i.e. moving from data to synthesis) involved in using framework synthesis?]

\section{Iteration described/discussed \\ No discussion of iteration}

\section{Epistemology?}

[Do authors state (or appear) that they are working from the premise that reality is a shared understanding?]

Subjective idealism [Subjective idealism: there is no shared reality independent of multiple alternative human constructions. Idealism=multiple complex viewpoints on a phenomenon; 'The originators of meta-narrative synthesis, critical interpretive synthesis and meta-study all articulate what might be termed a 'subjective idealist' approach to knowledge.' (Barnett-Page \& Thomas 2009:p.5)]

Objective idealism [Objective idealism: there is a world of collectively shared understandings. 'Methods used to synthesise grounded theory studies in order to produce a higher level of grounded theory [24] appear to be informed by 'objective idealism', as does meta-ethnography. Despite an assumption of a reality which is perhaps less contestable than those of meta-narrative synthesis, critical interpretive synthesis and meta-study, both grounded formal theory and meta- 
ethnography place a great deal of emphasis on the interpretive nature of their methods. This still supposes a degree of constructivism.' (Barnett-Page \& Thomas 2009:p.6)]

Critical realism [Critical realism: knowledge of reality is mediated by our perceptions and beliefs; Realism=there is one 'correct' view of a phenomenon Realist synthesis would fall under this epistemology.] Scientific realism [Scientific realism: it is possible for knowledge to approximate closely an external reality...'Although less explicit about how their methods are informed, it seems that both thematic synthesis and framework synthesis - while also involving some interpretation of data-share an even less problematized view of reality and a greater assumption that their synthetic products are reproducible and correspond to a shared reality.' (Barnett-Page \& Thomas 2009:p.6)]

Naïve realism [Nä̈ve realism: reality exists independently of human constructions and can be known directly [49,45,46].]

\section{Epistemology not described/unclear}

\section{Stakeholder involvement?}

[Were stakeholders consulted during the review? If so, how?]

Yes, described [Note how in info box; also use this box if it's unclear but you think stakeholder involvement took place during the review.]

No, not involved/not described [If authors do not describe stakeholder involvement please use this code.] 
Appendix 2. Table: Characteristics of included reports: Applied reviews

\begin{tabular}{|c|c|c|c|c|}
\hline Author, Year & Aims / Research Questions & $\begin{array}{l}\text { Design, A priori framework, } \\
\text { Methodology }\end{array}$ & $\begin{array}{l}\text { Country, Population, Number } \\
\text { of included studies }\end{array}$ & $\begin{array}{l}\text { Intended use of } \\
\text { findings }\end{array}$ \\
\hline $\begin{array}{l}\text { Brunton et al. } \\
(2006)\end{array}$ & $\begin{array}{l}\text { - to understand the fit } \\
\text { between determinants of } \\
\text { walking and cycling } \\
\text { identified by children and } \\
\text { parents and by interventions } \\
\text { addressing those determinants }\end{array}$ & $\begin{array}{l}\text { Design } \\
\text { MMRS } \\
\text { A priori framework } \\
\text { Developed from researcher } \\
\text { knowledge, background research and } \\
\text { stakeholder experience } \\
\text { Methodology } \\
\text { A priori framework developed from } \\
\text { review of stakeholder views } \\
\text { (qualitative) research then applied to } \\
\text { review of interventions; comparative } \\
\text { analysis of themes against intervention } \\
\text { aims }\end{array}$ & $\begin{array}{l}\text { Country } \\
\text { Qualitative research of } \\
\text { stakeholder views - UK } \\
\text { Intervention evaluations - } \\
\text { International } \\
\text { Population } \\
\text { Children, adolescents and } \\
\text { parents } \\
\text { Number of included studies } \\
\mathrm{N}=16 \text { qualitative studies } \\
\mathrm{N}=15 \text { intervention studies }\end{array}$ & $\begin{array}{l}\text { - policy need to } \\
\text { understand how to } \\
\text { facilitate more } \\
\text { physical activity } \\
\text { through active } \\
\text { transport }\end{array}$ \\
\hline $\begin{array}{l}\text { Brunton et al. } \\
(2014)\end{array}$ & $\begin{array}{l}\text { - to examine associations } \\
\text { between chronic hepatitis C } \\
\text { (HCV) infection and the } \\
\text { development of extrahepatic } \\
\text { conditions } \\
\text { - to understand the impact of } \\
\text { HCV infection or } \\
\text { extrahepatic conditions on } \\
\text { health-related quality of life }\end{array}$ & $\begin{array}{l}\text { Design } \\
\text { MMRS } \\
\text { A priori framework } \\
\text { Developed from researcher } \\
\text { knowledge, background research } \\
\text { Methodology } \\
\text { A priori framework developed from } \\
\text { mapping review of correlation studies } \\
\text { and stakeholder opinions which } \\
\text { informed meta-analysis of correlation } \\
\text { studies }\end{array}$ & $\begin{array}{l}\text { Country } \\
\text { International } \\
\text { Population } \\
\text { Adults co-infected with HCV } \\
\text { and } \\
\text { another chronic condition } \\
\text { Number of included studies } \\
\mathrm{N}=71 \text { studies included in meta- } \\
\text { analysis }\end{array}$ & $\begin{array}{l}\text { - to address } \\
\text { identified gaps in } \\
\text { current research } \\
\text { syntheses and to } \\
\text { inform policy and } \\
\text { practice on how to } \\
\text { address the needs of } \\
\text { people in the UK } \\
\text { living with chronic } \\
\text { HCV }\end{array}$ \\
\hline
\end{tabular}




\begin{tabular}{|c|c|c|c|c|}
\hline Author, Year & Aims / Research Questions & $\begin{array}{l}\text { Design, A priori framework, } \\
\text { Methodology }\end{array}$ & $\begin{array}{l}\text { Country, Population, Number } \\
\text { of included studies }\end{array}$ & $\begin{array}{l}\text { Intended use of } \\
\text { findings }\end{array}$ \\
\hline $\begin{array}{l}\text { Brunton et al. } \\
(2015)\end{array}$ & $\begin{array}{l}\text { - to examine the effectiveness } \\
\text { of community engagement } \\
\text { approaches in improving } \\
\text { health and well-being and } \\
\text { reducing health inequalities } \\
\text { - to determine which } \\
\text { processes of community } \\
\text { engagement are more aligned } \\
\text { with effective and ineffective } \\
\text { interventions }\end{array}$ & $\begin{array}{l}\text { Design } \\
\text { MMRS } \\
\text { A priori framework } \\
\text { Community engagement conceptual } \\
\text { framework (see O'Mara-Eves et al. } \\
2013 \text { ) } \\
\text { Methodology } \\
\text { A priori framework used to examine } \\
\text { more recent literature and test process } \\
\text { of community engagement using } \\
\text { meta-analysis }\end{array}$ & $\begin{array}{l}\text { Country } \\
\text { International } \\
\text { Population } \\
\text { General population } \\
\text { Number of included studies } \\
\mathrm{N}=26 \text { studies }\end{array}$ & $\begin{array}{l}\text { - to inform national } \\
\text { guidance on } \\
\text { community } \\
\text { engagement } \\
\text { strategies }\end{array}$ \\
\hline $\begin{array}{l}\text { Connell et al. } \\
(2012)\end{array}$ & $\begin{array}{l}\text { - to identify important quality } \\
\text { of life domains as identified } \\
\text { by those living with mental } \\
\text { health problems }\end{array}$ & $\begin{array}{l}\text { Design } \\
\text { QES } \\
\text { A priori framework } \\
\text { Framework developed from initial } \\
\text { themes arising from included studies } \\
\text { and background literature } \\
\text { Methodology } \\
\text { Thematic analysis of qualitative } \\
\text { research }\end{array}$ & $\begin{array}{l}\text { Country } \\
\text { International } \\
\text { Population } \\
\text { People living with mental health } \\
\text { issues } \\
\text { Number of included studies } \\
\mathrm{N}=13 \text { studies }\end{array}$ & $\begin{array}{l}\text { - part of a larger } \\
\text { funded research } \\
\text { project examining } \\
\text { mental health issues }\end{array}$ \\
\hline
\end{tabular}




\begin{tabular}{|c|c|c|c|c|}
\hline Author, Year & Aims / Research Questions & $\begin{array}{l}\text { Design, A priori framework, } \\
\text { Methodology }\end{array}$ & $\begin{array}{l}\text { Country, Population, Number } \\
\text { of included studies }\end{array}$ & $\begin{array}{l}\text { Intended use of } \\
\text { findings }\end{array}$ \\
\hline $\begin{array}{l}\text { Davies et al. } \\
\text { (2011) }\end{array}$ & $\begin{array}{l}\text { - to examine integrated } \\
\text { approaches to health care } \\
\text { provision for older people in } \\
\text { care homes } \\
\text { - to identify barriers and } \\
\text { facilitators to integrated } \\
\text { working }\end{array}$ & $\begin{array}{l}\text { Design } \\
\text { MMRS } \\
\text { A priori framework } \\
\text { Theory developed from included } \\
\text { literature } \\
\text { Methodology } \\
\text { Framework developed from qualitative } \\
\text { literature; narrative and comparative } \\
\text { analysis of barriers and facilitators } \\
\text { against identified interventions }\end{array}$ & $\begin{array}{l}\text { Country } \\
\text { International } \\
\text { Population } \\
\text { Elderly people in care homes } \\
\text { Number of included studies } \\
\mathrm{N}=17 \text { studies }\end{array}$ & - Not reported. \\
\hline $\begin{array}{l}\text { Dearden et al. } \\
(2015)\end{array}$ & $\begin{array}{l}\text { - to analyse prescribing error } \\
\text { literature to identify junior } \\
\text { doctors' behavioural skills } \\
\text { related to safe and effective } \\
\text { prescribing performance }\end{array}$ & $\begin{array}{l}\text { Design } \\
\text { QES } \\
\text { A priori framework } \\
\text { Theory of non-technical skill use } \\
\text { Methodology } \\
\text { Application of a priori theoretical } \\
\text { framework to mixed methods studies } \\
\text { of prescribing behaviour; thematic } \\
\text { analysis of identified categories }\end{array}$ & $\begin{array}{l}\text { Country } \\
\text { International } \\
\text { Population } \\
\text { Junior doctors or staff describing } \\
\text { prescribing behaviour similar to } \\
\text { those of junior doctors } \\
\text { Number of included studies } \\
\mathrm{N}=14 \text { studies }\end{array}$ & $\begin{array}{l}\text { - taxonomy } \\
\text { development to } \\
\text { facilitate teaching } \\
\text { and implementation } \\
\text { of a safe prescribing } \\
\text { tool for junior } \\
\text { doctors in hospitals }\end{array}$ \\
\hline
\end{tabular}




\begin{tabular}{|c|c|c|c|c|}
\hline Author, Year & Aims / Research Questions & $\begin{array}{l}\text { Design, A priori framework, } \\
\text { Methodology }\end{array}$ & $\begin{array}{l}\text { Country, Population, Number } \\
\text { of included studies }\end{array}$ & $\begin{array}{l}\text { Intended use of } \\
\text { findings }\end{array}$ \\
\hline $\begin{array}{l}\text { Demain et al. } \\
(2015)\end{array}$ & $\begin{array}{l}\text { - to describe the treatment- } \\
\text { generated disruptions patients } \\
\text { experience, and strategies } \\
\text { they employ to minimise } \\
\text { these disruptions, across all } \\
\text { chronic conditions and } \\
\text { treatments }\end{array}$ & $\begin{array}{l}\text { Design } \\
\text { QES } \\
\text { A priori framework } \\
\text { Cumulative Complexity Model } \\
\text { Methodology } \\
\text { Studies coded using Shippee's } \\
\text { framework and thematic synthesis } \\
\text { undertaken using a priori framework }\end{array}$ & $\begin{array}{l}\text { Country } \\
\text { International } \\
\text { Population } \\
\text { All ages experiencing a chronic } \\
\text { condition requiring treatment } \\
\text { Number of included studies } \\
\mathrm{N}=11 \text { studies }\end{array}$ & - Not reported \\
\hline $\begin{array}{l}\text { Fishwick et al. } \\
\text { (2012) }\end{array}$ & $\begin{array}{l}\text { - to understand employees' } \\
\text { views and preferences of } \\
\text { workplace smoking cessation } \\
\text { interventions and the factors } \\
\text { influencing their attitudes to } \\
\text { quitting smoking }\end{array}$ & $\begin{array}{l}\text { Design } \\
\text { QES } \\
\text { A priori framework } \\
\text { Transtheoretical Model } \\
\text { Methodology } \\
\text { Coding of the data into the framework } \\
\text { and generating new codes as needed; } \\
\text { thematic analysis of the relationships } \\
\text { between coded characteristics }\end{array}$ & $\begin{array}{l}\text { Country } \\
\text { Europe, North America, } \\
\text { Australasia } \\
\text { Population } \\
\text { Employees who had taken part } \\
\text { in workplace smoking cessation } \\
\text { programmes } \\
\text { Number of included studies } \\
\mathrm{N}=14 \text { studies }\end{array}$ & $\begin{array}{l}\text { - to complement } \\
\text { existing evidence of } \\
\text { effectiveness by } \\
\text { providing } \\
\text { information on } \\
\text { people's experiences } \\
\text { of workplace } \\
\text { smoking cessation } \\
\text { programmes }\end{array}$ \\
\hline $\begin{array}{l}\text { Gallacher et al. } \\
\text { (2013) }\end{array}$ & $\begin{array}{l}\text { - to examine treatment burden } \\
\text { in stroke patients, from the } \\
\text { patients' point of view }\end{array}$ & $\begin{array}{l}\text { Design } \\
\text { QES } \\
\text { A priori framework } \\
\text { Normalization Process Theory } \\
\text { Methodology } \\
\text { Application of the framework to code } \\
\text { studies; thematic synthesis of data }\end{array}$ & $\begin{array}{l}\text { Country } \\
\text { International } \\
\text { Population } \\
\text { Patients experiencing stroke and } \\
\text { related care } \\
\text { Number of included studies } \\
\mathrm{N}=69 \text { studies }\end{array}$ & $\begin{array}{l}\text { - to provide a } \\
\text { comprehensive } \\
\text { taxonomy and } \\
\text { conceptual model of } \\
\text { treatment burden in } \\
\text { stroke }\end{array}$ \\
\hline
\end{tabular}




\begin{tabular}{|c|c|c|c|c|}
\hline Author, Year & Aims / Research Questions & $\begin{array}{l}\text { Design, A priori framework, } \\
\text { Methodology }\end{array}$ & $\begin{array}{l}\text { Country, Population, Number } \\
\text { of included studies }\end{array}$ & $\begin{array}{l}\text { Intended use of } \\
\text { findings }\end{array}$ \\
\hline $\begin{array}{l}\text { Glenton et al. } \\
(2013)\end{array}$ & $\begin{array}{l}\text { - to explore barriers and } \\
\text { facilitators of implementation } \\
\text { of lay maternal-child health } \\
\text { worker (LHW) programmes }\end{array}$ & $\begin{array}{l}\text { Design } \\
\text { QES } \\
\text { A priori framework } \\
\text { SURE framework } \\
\text { Methodology } \\
\text { Studies coded using a priori } \\
\text { framework and thematic synthesis } \\
\text { undertaken }\end{array}$ & $\begin{array}{l}\text { Country } \\
\text { International } \\
\text { Population } \\
\text { Stakeholders of lay health } \\
\text { worker programmes in maternal } \\
\text { child health offered in primary } \\
\text { care settings } \\
\text { Number of included studies } \\
\mathrm{N}=53 \text { studies }\end{array}$ & $\begin{array}{l}\text { - to update and } \\
\text { extend a Cochrane } \\
\text { review }\end{array}$ \\
\hline $\begin{array}{l}\text { Horne \& Tierney } \\
(2012)\end{array}$ & $\begin{array}{l}\text { - to identify beliefs, culturally } \\
\text { appropriate strategies and } \\
\text { inter, intra, community and } \\
\text { organisational factors related } \\
\text { to the uptake of and } \\
\text { adherence to physical activity }\end{array}$ & $\begin{array}{l}\text { Design } \\
\text { QES } \\
\text { A priori framework } \\
\text { None reported } \\
\text { Methodology } \\
\text { Conceptual framework derived from } \\
\text { included studies }\end{array}$ & $\begin{array}{l}\text { Country } \\
\text { Canada, UK } \\
\text { Population } \\
\text { South Asian older adults } \\
\text { Number of included studies } \\
\mathrm{N}=11 \text { studies }\end{array}$ & $\begin{array}{l}- \text { to inform culturally } \\
\text { appropriate } \\
\text { intervention } \\
\text { development }\end{array}$ \\
\hline $\begin{array}{l}\text { Ingram et al. } \\
\text { (2012) }\end{array}$ & $\begin{array}{l}\text { - to examine the barriers and } \\
\text { facilitators to home safety } \\
\text { interventions designed to } \\
\text { prevent unintentional injuries } \\
\text { in pre-school children }\end{array}$ & $\begin{array}{l}\text { Design } \\
\text { QES } \\
\text { A priori framework } \\
\text { None reported } \\
\text { Methodology } \\
\text { Initial conceptual framework derived } \\
\text { from first } 10 \text { studies and developed } \\
\text { with remaining studies }\end{array}$ & $\begin{array}{l}\text { Country } \\
\text { International } \\
\text { Population } \\
\text { Children under } 5 \text { years old } \\
\text { Number of included studies } \\
\mathrm{N}=57\end{array}$ & - Not reported \\
\hline
\end{tabular}




\begin{tabular}{|c|c|c|c|c|}
\hline Author, Year & Aims / Research Questions & $\begin{array}{l}\text { Design, A priori framework, } \\
\text { Methodology }\end{array}$ & $\begin{array}{l}\text { Country, Population, Number } \\
\text { of included studies }\end{array}$ & $\begin{array}{l}\text { Intended use of } \\
\text { findings }\end{array}$ \\
\hline $\begin{array}{l}\text { Kruijsen-Terpstra } \\
\text { et al. (2014) }\end{array}$ & $\begin{array}{l}\text { - to give an overview of the } \\
\text { experiences and related } \\
\text { factors of parents of young } \\
\text { children with cerebral palsy } \\
\text { in relation to the physical } \\
\text { and/or occupational therapy } \\
\text { of their child in a } \\
\text { rehabilitation setting }\end{array}$ & $\begin{array}{l}\text { Design } \\
\text { MMRS } \\
\text { A priori framework } \\
\text { Family-Centred Care Model } \\
\text { Methodology } \\
\text { Data extracted from studies using the a } \\
\text { priori framework and thematic } \\
\text { synthesis conducted }\end{array}$ & $\begin{array}{l}\text { Country } \\
\text { International } \\
\text { Population } \\
\text { Parents of children under five } \\
\text { years old with cerebral palsy } \\
\text { Number of included studies } \\
\mathrm{N}=13 \text { studies }\end{array}$ & $\begin{array}{l}\text { - to understand } \\
\text { parents' perspectives } \\
\text { in order to more } \\
\text { fully engage them in } \\
\text { their child's care }\end{array}$ \\
\hline $\begin{array}{l}\text { Lloyd-Jones } \\
(2005)\end{array}$ & $\begin{array}{l}\text { - to describe the factors } \\
\text { influencing specialist and } \\
\text { advanced hospital-based } \\
\text { acute nursing role } \\
\text { development and effective } \\
\text { practice }\end{array}$ & $\begin{array}{l}\text { Design } \\
\text { QES } \\
\text { A priori framework } \\
\text { Not reported } \\
\text { Methodology } \\
\text { Framework synthesis method as per } \\
\text { Ritchie and Spencer }\end{array}$ & $\begin{array}{l}\text { Country } \\
\text { International } \\
\text { Population } \\
\text { Specialist and advanced } \\
\text { hospital-based acute nurses or } \\
\text { related stakeholders } \\
\text { Number of included studies } \\
\text { N=14 studies }\end{array}$ & - Not reported \\
\hline $\begin{array}{l}\text { Luckett et al. } \\
\text { (2013) }\end{array}$ & $\begin{array}{l}\text { - to understand barriers and } \\
\text { facilitators of adult cancer } \\
\text { pain assessment and } \\
\text { management }\end{array}$ & $\begin{array}{l}\text { Design } \\
\text { QES } \\
\text { A priori framework } \\
\text { Mead \& Bower's Person-Centred Care } \\
\text { Model } \\
\text { Methodology } \\
\text { Data coded into a priori framework } \\
\text { and thematic synthesis conducted }\end{array}$ & $\begin{array}{l}\text { Country } \\
\text { International } \\
\text { Population } \\
\text { Patients with cancer or other } \\
\text { involved stakeholders } \\
\text { Number of included studies } \\
\mathrm{N}=65 \text { studies }\end{array}$ & $\begin{array}{l}\text { - to inform the } \\
\text { management of pain } \\
\text { assessment and } \\
\text { treatment in patients } \\
\text { with cancer }\end{array}$ \\
\hline
\end{tabular}




\begin{tabular}{|c|c|c|c|c|}
\hline Author, Year & Aims / Research Questions & $\begin{array}{l}\text { Design, A priori framework, } \\
\text { Methodology }\end{array}$ & $\begin{array}{l}\text { Country, Population, Number } \\
\text { of included studies }\end{array}$ & $\begin{array}{l}\text { Intended use of } \\
\text { findings }\end{array}$ \\
\hline $\begin{array}{l}\text { McEvoy et al. } \\
(2014)\end{array}$ & $\begin{array}{l}\text { - to examine studies using } \\
\text { Normalization Process } \\
\text { Theory in order to understand } \\
\text { interventions, } \\
\text { operationalisation and } \\
\text { benefits }\end{array}$ & $\begin{array}{l}\text { Design } \\
\text { QES } \\
\text { A priori framework } \\
\text { Normalization Process Theory } \\
\text { Methodology } \\
\text { Framework developed from issues } \\
\text { emerging in the included studies; } \\
\text { thematic synthesis across identified } \\
\text { issues }\end{array}$ & $\begin{array}{l}\text { Country } \\
\text { International } \\
\text { Population } \\
\text { Studies using NPT to analyse } \\
\text { interventions } \\
\text { Number of included studies } \\
\text { N=29 studies }\end{array}$ & $\begin{array}{l}\text { - to build knowledge } \\
\text { on the use of theory } \\
\text { to inform } \\
\text { implementation } \\
\text { research }\end{array}$ \\
\hline $\begin{array}{l}\text { Mytton et al. } \\
(2013)\end{array}$ & $\begin{array}{l}\text { - to identify qualitative } \\
\text { studies of parents' views } \\
\text { about their engagement in } \\
\text { parenting programmes } \\
\text { - to compare these to } \\
\text { researchers' perceptions }\end{array}$ & $\begin{array}{l}\text { Design } \\
\text { QES } \\
\text { A priori framework } \\
\text { Previously published conceptual } \\
\text { framework of injury prevention in } \\
\text { children } \\
\text { Methodology } \\
\text { Data were coded into a priori } \\
\text { framework and results tabulated, } \\
\text { compared and subthemes examined }\end{array}$ & $\begin{array}{l}\text { Country } \\
\text { International } \\
\text { Population } \\
\text { Parents, providers and } \\
\text { researchers involved in } \\
\text { parenting programmes } \\
\text { Number of included studies } \\
\mathrm{N}=26\end{array}$ & $\begin{array}{l}\text { - to inform } \\
\text { intervention } \\
\text { development that } \\
\text { will ensure greater } \\
\text { parental uptake and } \\
\text { engagement }\end{array}$ \\
\hline
\end{tabular}




\begin{tabular}{|c|c|c|c|c|}
\hline Author, Year & Aims / Research Questions & $\begin{array}{l}\text { Design, A priori framework, } \\
\text { Methodology }\end{array}$ & $\begin{array}{l}\text { Country, Population, Number } \\
\text { of included studies }\end{array}$ & $\begin{array}{l}\text { Intended use of } \\
\text { findings }\end{array}$ \\
\hline $\begin{array}{l}\text { Noyes et al. } \\
(2013)\end{array}$ & $\begin{array}{l}\text { - to analyse stakeholders' } \\
\text { perspectives of the health } \\
\text { care 'transition process' in } \\
\text { order to establish the factors } \\
\text { critical to successful } \\
\text { discharge }\end{array}$ & $\begin{array}{l}\text { Design } \\
\text { MMRS } \\
\text { A priori framework } \\
\text { Conceptual framework developed } \\
\text { from researcher and key stakeholder } \\
\text { knowledge and three purposively } \\
\text { selected international discharge } \\
\text { guidelines } \\
\text { Methodology } \\
\text { Data extracted according to a priori } \\
\text { framework and thematic analysis } \\
\text { undertaken; range of study types } \\
\text { included }\end{array}$ & $\begin{array}{l}\text { Country } \\
\text { International } \\
\text { Population } \\
\text { Patients, caregivers, providers } \\
\text { and policy makers involved in } \\
\text { discharge from hospital } \\
\text { Number of included studies } \\
\text { N=34 studies }\end{array}$ & $\begin{array}{l}\text { - to enable } \\
\text { intervention } \\
\text { development and } \\
\text { process evaluation } \\
\text { across the health } \\
\text { care sector }\end{array}$ \\
\hline $\begin{array}{l}\text { Oliver et al. } \\
(2008)\end{array}$ & $\begin{array}{l}\text { - to understand public } \\
\text { stakeholder involvement in } \\
\text { agenda setting in health } \\
\text { research }\end{array}$ & $\begin{array}{l}\text { Design } \\
\text { MMRS } \\
\text { A priori framework } \\
\text { Developed from background research } \\
\text { scoping, researcher knowledge and } \\
\text { public consultation } \\
\text { Methodology } \\
\text { A priori conceptual framework } \\
\text { developed, then applied to located } \\
\text { research }\end{array}$ & $\begin{array}{l}\text { Country } \\
\text { International } \\
\text { Population } \\
\text { Members of the public involved } \\
\text { in health research agenda setting } \\
\text { Number of included studies } \\
\text { N=87 reports }\end{array}$ & $\begin{array}{l}\text { - to inform methods } \\
\text { of public } \\
\text { involvement in } \\
\text { research agenda } \\
\text { setting exercises }\end{array}$ \\
\hline
\end{tabular}




\begin{tabular}{|c|c|c|c|c|}
\hline Author, Year & Aims / Research Questions & $\begin{array}{l}\text { Design, A priori framework, } \\
\text { Methodology }\end{array}$ & $\begin{array}{l}\text { Country, Population, Number } \\
\text { of included studies }\end{array}$ & $\begin{array}{l}\text { Intended use of } \\
\text { findings }\end{array}$ \\
\hline $\begin{array}{l}\text { O’Mara-Eves et } \\
\text { al. (2013) }\end{array}$ & $\begin{array}{l}\text { - to identify, describe and } \\
\text { analyse effective (and cost } \\
\text { effective) community } \\
\text { engagement approaches for } \\
\text { disadvantaged populations } \\
\text { and/or reducing inequalities } \\
\text { in health } \\
\text { - to identify the range of } \\
\text { models, approaches and } \\
\text { mechanisms underpinning } \\
\text { community engagement }\end{array}$ & $\begin{array}{l}\text { Design } \\
\text { MMRS } \\
\text { A priori framework } \\
\text { Community engagement framework } \\
\text { developed by Oliver et al. (2005) } \\
\text { Methodology } \\
\text { A priori framework applied to } \\
\text { intervention evaluations; meta- } \\
\text { analysis of interventions; qualitative } \\
\text { comparative analysis of processes of } \\
\text { community engagement }\end{array}$ & $\begin{array}{l}\text { Country } \\
\text { International } \\
\text { Population } \\
\text { Disadvantaged populations of all } \\
\text { ages } \\
\text { Number of included studies } \\
\mathrm{N}=131 \text { studies included in meta- } \\
\text { analysis }\end{array}$ & $\begin{array}{l}\text { - funder need to } \\
\text { understand theory, } \\
\text { effectiveness and } \\
\text { cost effectiveness of } \\
\text { community } \\
\text { engagement } \\
\text { approaches }\end{array}$ \\
\hline Ram et al. (2008) & $\begin{array}{l}\text { - to identify methods used to } \\
\text { engage medical device users } \\
\text { in device development and } \\
\text { evaluation } \\
\text { - to examine methods for user } \\
\text { perspectives }\end{array}$ & $\begin{array}{l}\text { Design } \\
\text { MMRS } \\
\text { A priori framework } \\
\text { Not reported } \\
\text { Methodology } \\
\text { Themes iteratively developed from } \\
\text { included reports }\end{array}$ & $\begin{array}{l}\text { Country } \\
\text { International } \\
\text { Population } \\
\text { Medical device users } \\
\text { Number of included studies } \\
\mathrm{N}=45 \text { reports }\end{array}$ & $\begin{array}{l}\text { - to inform } \\
\text { promising } \\
\text { approaches to user } \\
\text { involvement in } \\
\text { medical device } \\
\text { design }\end{array}$ \\
\hline
\end{tabular}




\begin{tabular}{|c|c|c|c|c|}
\hline Author, Year & Aims / Research Questions & $\begin{array}{l}\text { Design, A priori framework, } \\
\text { Methodology }\end{array}$ & $\begin{array}{l}\text { Country, Population, Number } \\
\text { of included studies }\end{array}$ & $\begin{array}{l}\text { Intended use of } \\
\text { findings }\end{array}$ \\
\hline $\begin{array}{l}\text { Rimstad et al. } \\
(2015)\end{array}$ & $\begin{array}{l}\text { - to understand the underlying } \\
\text { assumptions, provider roles } \\
\text { and performance } \\
\text { measurement for incident } \\
\text { command systems (ICS) }\end{array}$ & $\begin{array}{l}\text { Design } \\
\text { MMRS } \\
\text { A priori framework } \\
\text { A priori framework based on project } \\
\text { research questions, coding tool based } \\
\text { on American ICS guidelines } \\
\text { Methodology } \\
\text { Data extracted from papers using } \\
\text { coding tool and framework analysis } \\
\text { methods used to populate three } \\
\text { research questions }\end{array}$ & $\begin{array}{l}\text { Country } \\
\text { International } \\
\text { Population } \\
\text { Emergency situations requiring } \\
\text { ICS } \\
\text { Number of included studies } \\
\mathrm{N}=76 \text { studies }\end{array}$ & $\begin{array}{l}\text { - to improve } \\
\text { emergency } \\
\text { management systems }\end{array}$ \\
\hline $\begin{array}{l}\text { Sohanpal et al. } \\
(2015)\end{array}$ & $\begin{array}{l}\text { - to explore factors } \\
\text { influencing patient } \\
\text { participation in studies of } \\
\text { chronic obstructive } \\
\text { pulmonary disease (COPD) } \\
\text { self-management and } \\
\text { rehabilitation programmes }\end{array}$ & $\begin{array}{l}\text { Design } \\
\text { QES } \\
\text { A priori framework } \\
\text { Attitude-social influence-external } \\
\text { barriers Model and Self-regulation } \\
\text { Model } \\
\text { Methodology } \\
\text { Translation of concepts from included } \\
\text { studies into one another; themes } \\
\text { developed which were mapped onto a } \\
\text { priori conceptual framework and new } \\
\text { themes developed }\end{array}$ & $\begin{array}{l}\text { Country } \\
\text { International } \\
\text { Population } \\
\text { Patients with COPD } \\
\text { Number of included studies } \\
\mathrm{N}=10 \text { studies }\end{array}$ & $\begin{array}{l}\text { - to improve } \\
\text { participation in } \\
\text { chronic disease } \\
\text { rehabilitation } \\
\text { programmes }\end{array}$ \\
\hline $\begin{array}{l}\text { Tierney et al. } \\
(2011)\end{array}$ & $\begin{array}{l}\text { - to examine barriers and } \\
\text { enablers to exercise/physical }\end{array}$ & $\begin{array}{l}\text { Design } \\
\text { QES }\end{array}$ & $\begin{array}{l}\text { Country } \\
\text { International }\end{array}$ & $\begin{array}{l}- \text { to inform } \\
\text { intervention }\end{array}$ \\
\hline
\end{tabular}




\begin{tabular}{|c|c|c|c|c|}
\hline Author, Year & Aims / Research Questions & $\begin{array}{l}\text { Design, A priori framework, } \\
\text { Methodology }\end{array}$ & $\begin{array}{l}\text { Country, Population, Number } \\
\text { of included studies }\end{array}$ & $\begin{array}{l}\text { Intended use of } \\
\text { findings }\end{array}$ \\
\hline & $\begin{array}{l}\text { activity among people with } \\
\text { heart failure }\end{array}$ & $\begin{array}{l}\text { A priori framework } \\
\text { Not reported } \\
\text { Methodology } \\
\text { Developing a framework after } \\
\text { familiarisation with the data, with } \\
\text { thematic synthesis following. }\end{array}$ & $\begin{array}{l}\text { Population } \\
\text { Patients with coronary heart } \\
\text { failure } \\
\text { Number of included studies } \\
\mathrm{N}=20 \text { studies }\end{array}$ & $\begin{array}{l}\text { development by } \\
\text { providing the } \\
\text { perspective of } \\
\text { patients }\end{array}$ \\
\hline $\begin{array}{l}\text { Tierney et al. } \\
(2013)\end{array}$ & $\begin{array}{l}\text { - What are participants' } \\
\text { experiences of receiving } \\
\text { health care, interacting with } \\
\text { others, and potential } \\
\text { interventions when pregnant } \\
\text { with an eating disorder? }\end{array}$ & $\begin{array}{l}\text { Design } \\
\text { QES } \\
\text { A priori framework } \\
\text { Not reported } \\
\text { Methodology } \\
\text { Four initial themes identified from } \\
\text { charting, with three additional themes } \\
\text { derived from examining the data } \\
\text { within initial themes }\end{array}$ & $\begin{array}{l}\text { Country } \\
\text { International } \\
\text { Population } \\
\text { Pregnant women with an eating } \\
\text { disorder } \\
\text { Number of included studies } \\
\mathrm{N}=7 \text { studies }\end{array}$ & $\begin{array}{l}\text { - to inform health } \\
\text { policy and practice }\end{array}$ \\
\hline $\begin{array}{l}\text { Walt \& Gilson } \\
(2014)\end{array}$ & $\begin{array}{l}\text { - to explore influences of } \\
\text { health policy papers on } \\
\text { agenda setting }\end{array}$ & $\begin{array}{l}\text { Design } \\
\text { QES } \\
\text { A priori framework }\end{array}$ & $\begin{array}{l}\text { Country } \\
\text { International } \\
\text { Population }\end{array}$ & $\begin{array}{l}\text { - to advance } \\
\text { understanding of } \\
\text { health policy agenda } \\
\text { setting and inform } \\
\text { theory development }\end{array}$ \\
\hline
\end{tabular}




\begin{tabular}{|c|c|c|c|c|}
\hline Author, Year & Aims / Research Questions & $\begin{array}{l}\text { Design, A priori framework, } \\
\text { Methodology }\end{array}$ & $\begin{array}{l}\text { Country, Population, Number } \\
\text { of included studies }\end{array}$ & $\begin{array}{l}\text { Intended use of } \\
\text { findings }\end{array}$ \\
\hline & $\begin{array}{l}\text { - to assess how far existing } \\
\text { framework might benefit } \\
\text { from adaptation }\end{array}$ & $\begin{array}{l}\text { Shiffman \& Smith priority-setting } \\
\text { framework } \\
\text { Methodology } \\
\text { Data extracted into the framework and } \\
\text { themes developed iteratively }\end{array}$ & $\begin{array}{l}\text { Examples of health policy } \\
\text { agenda setting } \\
\text { Number of included studies } \\
\mathrm{N}=22 \text { studies }\end{array}$ & \\
\hline $\begin{array}{l}\text { Watson et al. } \\
\text { (2011) }\end{array}$ & $\begin{array}{l}\text { - To identify evidence and } \\
\text { models of best practice in } \\
\text { transitional care for children } \\
\text { with chronic health needs }\end{array}$ & $\begin{array}{l}\text { Design } \\
\text { QES } \\
\text { A priori framework } \\
\text { Background literature to thematically } \\
\text { summarise best practice in transition } \\
\text { care, integrated with Normalization } \\
\text { Process Theory } \\
\text { Methodology } \\
\text { Studies coded into a priori framework } \\
\text { and summarised }\end{array}$ & $\begin{array}{l}\text { Country } \\
\text { International } \\
\text { Population } \\
\text { Examples of transition care for } \\
\text { children with cerebral palsy, } \\
\text { diabetes and autism spectrum } \\
\text { disorders } \\
\text { Number of included studies } \\
\text { N=19 studies }\end{array}$ & $\begin{array}{l}\text { - to inform future } \\
\text { intervention } \\
\text { development }\end{array}$ \\
\hline $\begin{array}{l}\text { Wilman et al. } \\
(2015)\end{array}$ & $\begin{array}{l}\text { - to understand ethically } \\
\text { defensible approaches to } \\
\text { obtaining informed consent in } \\
\text { perinatal clinical trials }\end{array}$ & $\begin{array}{l}\text { Design } \\
\text { MMRS } \\
\text { A priori framework }\end{array}$ & $\begin{array}{l}\text { Country } \\
\text { International } \\
\text { Population }\end{array}$ & $\begin{array}{l}\text { - to provide an } \\
\text { ethical method for } \\
\text { conducting neonatal } \\
\text { research }\end{array}$ \\
\hline
\end{tabular}




\begin{tabular}{|l|l|l|l|l|}
\hline Author, Year & Aims / Research Questions & $\begin{array}{l}\text { Design, A priori framework, } \\
\text { Methodology }\end{array}$ & $\begin{array}{l}\text { Country, Population, Number } \\
\text { of included studies }\end{array}$ & $\begin{array}{l}\text { Intended use of } \\
\text { findings }\end{array}$ \\
\hline & & $\begin{array}{l}\text { Initial conceptual framework based on } \\
\text { prior conceptual knowledge of } \\
\text { informed consent philosophies } \\
\text { Methodology } \\
\text { Data extracted from included reports } \\
\text { into conceptual framework and } \\
\text { thematic analysis conducted }\end{array}$ & $\begin{array}{l}\text { sick infants; methods papers of } \\
\text { informed consent procedures. } \\
\text { Number of included studies } \\
\text { N=49 studies }\end{array}$ \\
& & & \\
\end{tabular}




\section{Appendix 3. ENTREQ Checklist}

\begin{tabular}{|c|c|c|}
\hline Item & Guide and Description & Described in... \\
\hline $1 \mathrm{Aim}$ & $\begin{array}{l}\text { State the research question the } \\
\text { synthesis addresses. }\end{array}$ & Introduction section (p.5). \\
\hline $\begin{array}{l}2 \text { Synthesis } \\
\text { Methodology }\end{array}$ & $\begin{array}{l}\text { Identify the synthesis methodology } \\
\text { or theoretical framework which } \\
\text { underpins the synthesis and } \\
\text { describe the rationale for choice of } \\
\text { methodology. }\end{array}$ & $\begin{array}{l}\text { Synthesis and quality appraisal } \\
\text { section (p.8). }\end{array}$ \\
\hline $\begin{array}{l}3 \text { Approach to } \\
\text { searching }\end{array}$ & $\begin{array}{l}\text { Indicate whether the search was } \\
\text { pre-planned (comprehensive search } \\
\text { strategies to seek all available } \\
\text { studies) or iterative (to seek all } \\
\text { available concepts until theoretical } \\
\text { saturation is achieved). }\end{array}$ & Searching section (p.6). \\
\hline $\begin{array}{l}4 \text { Inclusion } \\
\text { criteria }\end{array}$ & $\begin{array}{l}\text { Specify the inclusion/exclusion } \\
\text { criteria (e.g. in terms of population, } \\
\text { language, year limits, type of } \\
\text { publication, study type). }\end{array}$ & $\begin{array}{l}\text { Inclusion screening section } \\
\text { (p.7). }\end{array}$ \\
\hline $\begin{array}{l}\mathbf{5} \text { Data } \\
\text { sources }\end{array}$ & $\begin{array}{l}\text { Describe the information sources } \\
\text { used (e.g. electronic databases } \\
\text { (MEDLINE, EMBASE, CINAHL, } \\
\text { PsycINFO, Econlit), grey literature } \\
\text { databases (digital thesis, policy } \\
\text { reports), relevant organisational } \\
\text { websites, experts, information } \\
\text { specialists, generic web searches } \\
\text { (Google Scholar) hand searching, } \\
\text { reference lists) and when the } \\
\text { searches conducted; provide the } \\
\text { rationale for using the data sources. }\end{array}$ & Searching section (p.6). \\
\hline $\begin{array}{l}6 \text { Electronic } \\
\text { search } \\
\text { strategy }\end{array}$ & $\begin{array}{l}\text { Describe the literature search (e.g. } \\
\text { provide electronic search strategies } \\
\text { with population terms, clinical or } \\
\text { health topic terms, experiential or } \\
\text { social phenomena related terms, } \\
\text { filters for qualitative research, and } \\
\text { search limits). }\end{array}$ & Searching section (p.6). \\
\hline
\end{tabular}




\begin{tabular}{|c|c|c|}
\hline Item & Guide and Description & Described in... \\
\hline $\begin{array}{l}7 \text { Study } \\
\text { screening } \\
\text { methods }\end{array}$ & $\begin{array}{l}\text { Describe the process of study } \\
\text { screening and sifting (e.g. title, } \\
\text { abstract and full text review, } \\
\text { number of independent reviewers } \\
\text { who screened studies). }\end{array}$ & $\begin{array}{l}\text { Inclusion screening section } \\
\text { (p.7); Quality assurance section } \\
\text { (p.9). }\end{array}$ \\
\hline $\begin{array}{l}8 \text { Study } \\
\text { characteristics }\end{array}$ & $\begin{array}{l}\text { Present the characteristics of the } \\
\text { included studies (e.g. year of } \\
\text { publication, country, population, } \\
\text { number of participants, data } \\
\text { collection, methodology, analysis, } \\
\text { research questions). }\end{array}$ & Appendix 2 (p.24). \\
\hline $\begin{array}{l}9 \text { Study } \\
\text { selection } \\
\text { results }\end{array}$ & $\begin{array}{l}\text { Identify the number of studies } \\
\text { screened and provide reasons for } \\
\text { study exclusion (e,g, for } \\
\text { comprehensive searching, provide } \\
\text { numbers of studies screened and } \\
\text { reasons for exclusion indicated in a } \\
\text { figure/flowchart; for iterative } \\
\text { searching describe reasons for } \\
\text { study exclusion and inclusion based } \\
\text { on modifications to the research } \\
\text { question and/or contribution to } \\
\text { theory development). }\end{array}$ & $\begin{array}{l}\text { Indexing section (p.10); this } \\
\text { includes figure depicting flow of } \\
\text { reports through the review } \\
\text { process. }\end{array}$ \\
\hline $\begin{array}{l}10 \text { Rationale } \\
\text { for appraisal }\end{array}$ & $\begin{array}{l}\text { Describe the rationale and } \\
\text { approach used to appraise the } \\
\text { included studies or selected findings } \\
\text { (e.g. assessment of conduct (validity } \\
\text { and robustness), assessment of } \\
\text { reporting (transparency), } \\
\text { assessment of content and utility of } \\
\text { the findings). }\end{array}$ & $\begin{array}{l}\text { Synthesis and quality appraisal } \\
\text { section (p.10). }\end{array}$ \\
\hline $\begin{array}{l}11 \text { Appraisal } \\
\text { items }\end{array}$ & $\begin{array}{l}\text { State the tools, frameworks and } \\
\text { criteria used to appraise the studies } \\
\text { or selected findings (e.g. Existing } \\
\text { tools: CASP, QARI, COREQ, Mays } \\
\text { and Pope [25]; reviewer developed } \\
\text { tools; describe the domains } \\
\text { assessed: research team, study }\end{array}$ & $\begin{array}{l}\text { Synthesis and quality appraisal } \\
\text { section (p.8) describes rationale } \\
\text { for critical assessment of } \\
\text { included reports and rationale } \\
\text { for not using standard tool. }\end{array}$ \\
\hline
\end{tabular}




\begin{tabular}{|c|c|c|}
\hline Item & Guide and Description & Described in... \\
\hline & $\begin{array}{l}\text { design, data analysis and } \\
\text { interpretations, reporting). }\end{array}$ & \\
\hline $\begin{array}{l}12 \text { Appraisal } \\
\text { process }\end{array}$ & $\begin{array}{l}\text { Indicate whether the appraisal was } \\
\text { conducted independently by more } \\
\text { than one reviewer and if consensus } \\
\text { was required. }\end{array}$ & $\begin{array}{l}\text { Quality assurance of the review } \\
\text { (p.9). }\end{array}$ \\
\hline $\begin{array}{l}13 \text { Appraisal } \\
\text { results }\end{array}$ & $\begin{array}{l}\text { Present results of the quality } \\
\text { assessment and indicate which } \\
\text { articles, if any, were } \\
\text { weighted/excluded based on the } \\
\text { assessment and give the rationale. }\end{array}$ & $\begin{array}{l}\text { Synthesis and quality appraisal } \\
\text { section ( } p .8 \text { ) describes rationale } \\
\text { for critical assessment of } \\
\text { included reports and rationale } \\
\text { for not using standard tool; } \\
\text { Quality assurance of the review } \\
\text { (p.9) describes use of two } \\
\text { researchers to extract, analyse } \\
\text { and consider framework } \\
\text { development. }\end{array}$ \\
\hline $\begin{array}{l}14 \text { Data } \\
\text { extraction }\end{array}$ & $\begin{array}{l}\text { Indicate which sections of the } \\
\text { primary studies were analysed and } \\
\text { how were the data extracted from } \\
\text { the primary studies? (e.g. all text } \\
\text { under the headings "results } \\
\text { /conclusions" were extracted } \\
\text { electronically and entered into a } \\
\text { computer software). }\end{array}$ & $\begin{array}{l}\text { Data extraction section (p.8); } \\
\text { Quality assurance of the review } \\
\text { section (p.9). }\end{array}$ \\
\hline 15 Software & $\begin{array}{l}\text { State the computer software used, } \\
\text { if any. }\end{array}$ & $\begin{array}{l}\text { Quality assurance of the review } \\
\text { section (p.9). }\end{array}$ \\
\hline $\begin{array}{l}16 \text { Number of } \\
\text { reviewers }\end{array}$ & $\begin{array}{l}\text { Identify who was involved in coding } \\
\text { and analysis. }\end{array}$ & $\begin{array}{l}\text { Quality assurance of the review } \\
\text { section (p.9). }\end{array}$ \\
\hline 17 Coding & $\begin{array}{l}\text { Describe the process for coding of } \\
\text { data (e.g. line by line coding to } \\
\text { search for concepts). }\end{array}$ & Data extraction section (p.8). \\
\hline $\begin{array}{l}18 \text { Study } \\
\text { comparison }\end{array}$ & $\begin{array}{l}\text { Describe how were comparisons } \\
\text { made within and across studies (e.g. } \\
\text { subsequent studies were coded into } \\
\text { pre-existing concepts, and new } \\
\text { concepts were created when } \\
\text { deemed necessary). }\end{array}$ & $\begin{array}{l}\text { Synthesis and quality appraisal } \\
\text { section (p.8). }\end{array}$ \\
\hline
\end{tabular}




\begin{tabular}{|c|c|c|}
\hline Item & Guide and Description & Described in... \\
\hline $\begin{array}{l}19 \text { Derivation } \\
\text { of themes }\end{array}$ & $\begin{array}{l}\text { Explain whether the process of } \\
\text { deriving the themes or constructs } \\
\text { was inductive or deductive. }\end{array}$ & $\begin{array}{l}\text { Synthesis and quality appraisal } \\
\text { section (p.8). }\end{array}$ \\
\hline 20 Quotations & $\begin{array}{l}\text { Provide quotations from the } \\
\text { primary studies to illustrate } \\
\text { themes/constructs and identify } \\
\text { whether the quotations were } \\
\text { participant quotations of the } \\
\text { author's interpretation. }\end{array}$ & $\begin{array}{l}\text { Specific quotes from included } \\
\text { reports are included } \\
\text { throughout. }\end{array}$ \\
\hline $\begin{array}{l}21 \text { Synthesis } \\
\text { output }\end{array}$ & $\begin{array}{l}\text { Present rich, compelling and useful } \\
\text { results that go beyond a summary } \\
\text { of the primary studies (e.g. new } \\
\text { interpretation, models of evidence, } \\
\text { conceptual models, analytical } \\
\text { framework, development of a new } \\
\text { theory or construct). }\end{array}$ & Interpretation section (p.16-17). \\
\hline
\end{tabular}


